\title{
Forest biodiversity, ecosystem functioning and the provision of ecosystem services
}

\author{
Eckehard G. Brockerhoff $^{1} \cdot$ Luc Barbaro $^{2} \cdot$ Bastien Castagneyrol $^{3}$ • \\ David I. Forrester ${ }^{4}$ - Barry Gardiner ${ }^{5}$ - José Ramón González-Olabarria ${ }^{6}$.

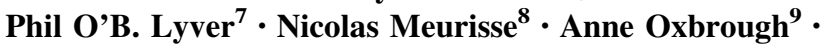 \\ Hisatomo Taki $^{10}$ - Ian D. Thompson ${ }^{11}$ - Fons van der Plas ${ }^{12}$ • \\ Hervé Jactel ${ }^{3}$
}

Published online: 4 November 2017

(c) Springer Science+Business Media B.V. 2017

\begin{abstract}
Forests are critical habitats for biodiversity and they are also essential for the provision of a wide range of ecosystem services that are important to human well-being. There is increasing evidence that biodiversity contributes to forest ecosystem functioning and the provision of ecosystem services. Here we provide a review of forest ecosystem services including biomass production, habitat provisioning services, pollination, seed dispersal, resistance to wind storms, fire regulation and mitigation, pest regulation of native
\end{abstract}

Communicated by David Hawksworth.

Electronic supplementary material The online version of this article (doi:10.1007/s10531-017-1453-2) contains supplementary material, which is available to authorized users.

Eckehard G. Brockerhoff

eckehard.brockerhoff@scionresearch.com

1 Scion (New Zealand Forest Research Institute), PO Box 29237, Christchurch 8440, New Zealand

2 Dynafor, INPT, EI Purpan, INRA, Univ. Toulouse, Auzeville, France

3 BIOGECO, INRA, University of Bordeaux, 33610 Cestas, France

4 Swiss Federal Institute of Forest, Snow and Landscape Research WSL, 8903 Birmensdorf, Switzerland

5 EFI Atlantic, 69 Route D’Arcachon, 33612 Cestas, France

6 Forest Sciences Centre of Catalonia, CTFC, Ctra de St. Llorenç de Morunys km 2, 25280 Solsona, Spain

7 Manaaki Whenua - Landcare Research, PO Box 69040, Lincoln 7640, New Zealand

8 Scion (New Zealand Forest Research Institute), 49 Sala Street, Rotorua 3046, New Zealand

9 Department of Biology, Edge Hill University, Ormskirk, Lancashire L39 4QP, UK

10 Forestry and Forest Products Research Institute, 1 Matsunosato, Tsukuba, Ibaraki 305-8687, Japan

11 Canadian Forest Service, Natural Resources Canada, Sault Ste. Marie, ON P6A 2E5, Canada

12 Department of Systematic Botany and Functional Biodiversity, University of Leipzig, Johannisallee 21-23, 04103 Leipzig, Germany 
and invading insects, carbon sequestration, and cultural ecosystem services, in relation to forest type, structure and diversity. We also consider relationships between forest biodiversity and multifunctionality, and trade-offs among ecosystem services. We compare the concepts of ecosystem processes, functions and services to clarify their definitions. Our review of published studies indicates a lack of empirical studies that establish quantitative and causal relationships between forest biodiversity and many important ecosystem services. The literature is highly skewed; studies on provisioning of nutrition and energy, and on cultural services, delivered by mixed-species forests are under-represented. Planted forests offer ample opportunity for optimising their composition and diversity because replanting after harvesting is a recurring process. Planting mixed-species forests should be given more consideration as they are likely to provide a wider range of ecosystem services within the forest and for adjacent land uses. This review also serves as the introduction to this special issue of Biodiversity and Conservation on various aspects of forest biodiversity and ecosystem services.

Keywords Ecological processes · Mixed-species forest · Planted forest · Tree diversity

\section{Introduction}

Forests and woodlands harbour immense terrestrial and aquatic biodiversity and, especially in moist tropical regions, represent the most species-rich habitat type worldwide (Mace et al. 2005; Lindenmayer 2009; Gibson et al. 2011). Pressures from human activities leading to forest loss, fragmentation and degradation (FAO 2015) have already caused much biodiversity decline and homogenization (Lindenmayer and Franklin 2002; Newbold et al. 2015; van der Plas et al. 2016b). These declines are expected to continue (e.g., Newbold et al. 2015), especially in the rich forests of Central and South America, South and Southeast Asia and Africa, although the rate of forest loss has been slowing in recent years (Keenan et al. 2015). Conversely, the area of planted forests (including plantation forests) is increasing and is currently ca. 7\% of total forest cover (Payn et al. 2015).

Collectively, these trends in forest cover and condition are a major concern, not only because of the implications for the conservation of biodiversity, but also because forests provide a wide range of critically important ecosystem services such as climate regulation, biomass production, water supply and purification, pollination, and the provision of habitats for forest species (Bauhus et al. 2010; Thompson et al. 2011; Brockerhoff et al. 2013; Decocq et al. 2016; Liang et al. 2016; Mori et al. 2017). There is also increasing evidence that the provision of ecosystem services is related to aspects of biodiversity; there is a positive relationship between biodiversity and most ecosystem services (e.g., Hooper et al. 2005; Balvanera et al. 2006; Isbell et al. 2011; Gamfeldt et al. 2013).

A wide range of mechanisms have been proposed to explain the relationships between biodiversity and ecosystem services. Niche complementarity in time and space, and complementarity of functional effect traits and functional response traits are all likely to be involved (Isbell et al. 2011). Facilitation between plant species growing together has often been found to lead to enhanced growth of certain tree mixtures (Thompson et al. 2014). For example, at nitrogen-limited sites, tree species that are nitrogen-fixers may enhance the growth of other tree species in mixed stands (e.g., Binkley 2003; Forrester and Bauhus 2016). Resistance to disturbance is facilitated by forest and tree diversity, leading to a reduction or dilution of resources (e.g., for herbivores), diversion or disruption, and multi- 
trophic interactions (e.g., enhanced abundance and action of natural enemies) (Jactel et al. 2017). Finally, the so-called 'sampling effect' can enhance the provision of ecosystem services, simply because the presence of more species increases the likelihood that an ecosystem will contain a species that grows faster, is more resistant to a particular disturbance, or has some other advantageous trait that leads to enhanced ecosystem functioning or provision of services, compared to communities with fewer species (Wardle 2001; Lefcheck et al. 2015).

Given the role of biodiversity in the provision of ecosystem services, the widespread degradation of forests is likely to have far-reaching effects, such as reduced resistance (or increased susceptibility) to natural or anthropogenic disturbance. As such disturbances appear to be increasing in frequency and intensity (e.g., Pachauri et al. 2014; Brockerhoff and Liebhold 2017; Freer-Smith and Webber 2017) declines in biodiversity are likely to reduce forests' resistance to climate extremes (e.g., Isbell et al. 2015) and to pests, pathogens, invasive species, and other disturbance factors (e.g., Jactel et al. 2017), and to reduce the provision of ecosystem services in general (e.g., Vilà and Hulme 2016).

Compared with 'natural forests' or mixed-species forests, planted forests usually have a lower level of biodiversity of canopy trees and other species (e.g., Barlow et al. 2007; Brockerhoff et al. 2008), and it is likely that their ability to provide certain ecosystem services is reduced. For example, mixed forests tend to be more effective in delivering a range of provisioning services (e.g., Gamfeldt et al. 2013; Forrester and Bauhus 2016), and are more resistant to various disturbances than single-species planted forests (Jactel et al. 2017). These relationships between forest type, biodiversity and ecosystem services are highly relevant for informing forest policy and management. However, given the multitude of ecosystem services, it is difficult to generalise about the role of forest diversity. Furthermore, there are trade-offs between different ecosystem services depending on the tree mixture and stand type involved. Some tree mixtures are superior at providing certain services but other tree mixtures or even single-species forests are more effective for other services (e.g., van der Plas et al. 2016a).

There has been much progress recently in this very active field of research, and the International Union of Forest Research Organisations (IUFRO) established a task force to facilitate multi-disciplinary research collaboration and literature reviews on the effects of forest biodiversity on single and multiple ecosystem services. The current paper provides a general literature review on this topic and serves as an introduction to a special issue consisting of 10 papers on various aspects of forest biodiversity, ecosystem services and related issues. Habitat provision is a central theme for several contributions. A review of analytical methods using readily-available forest inventory data for biodiversity assessments is provided by Corona et al. (2017). The effects of afforestation of open land on bird communities and biodiversity in Ireland and Argentina are examined by Graham et al. (2017) and Phifer et al. (2017), respectively, highlighting the importance of considering the previous land use context. For example, while afforestation of Irish peatlands and grasslands of high conservation value was considered detrimental for bird biodiversity, in the case of intensively managed grassland, afforestation can lead to higher densities of bird species of conservation concern (Graham et al. 2017). Such nuanced observations are particularly important in areas that have experienced severe deforestation (Brockerhoff et al. 2008), such as Ireland where only $1 \%$ of the land area remains in natural woodland (O'Callaghan et al. 2017). Under such circumstances, even plantations of exotic trees can provide important habitats for forest species, although attention needs to be given to management options that enhance the value for forest specialists and species of conservation concern (O'Callaghan et al. 2017). The maintenance of ecosystem services provided 
by aquatic biota in managed forests in north-western North America is examined by Penaluna et al. (2017). They highlight the complex nature of relationships between aquatic biodiversity and numerous ecosystem services and the need for better quantification and understanding of process interactions. Pollination of crop plants and wild plants is an important ecosystem service worldwide. Taki et al. (2017) explore the use of stable isotope analysis to investigate how land use and climate affect wild bee populations. This provides a useful approach for the study of relationships between biodiversity, land use and the provision of pollination services. The effects of invasions of tree pests and pathogens on forest biodiversity and ecosystem services are assessed by Freer-Smith and Webber (2017), highlighting the urgent need to mitigate the risk of future invasions and to increase our ability to manage those that have already occurred. Cultural ecosystem services are highly relevant in indigenous communities. Lyver et al. (2017a, b) use interviews with members of an indigenous tribe in New Zealand that has strong connections with the surrounding forest to assess temporal changes in forest use and perceptions of forest health. Finally, Vangansbeke et al. (2017) examine trade-offs between biodiversity, wood production and recreation in planted pine forests and how forest management planning can be optimised spatially to integrate the delivery of multiple ecosystem services.

The objectives of this paper are to: (1) provide an overview of the various 'ecosystem services' that are provided by forests; (2) clarify the definitions of ecological processes, ecosystem function, and ecosystem services and goods; and (3) review and synthesise the current state of knowledge regarding forest ecosystem services and the role of forest biodiversity in the provision of these ecosystem services.

\section{Ecosystem processes, functions, services are distinct concepts}

It is widely recognized that biodiversity is a major driving force in ecosystem function (Hooper et al. 2005; Schulze and Mooney 2012). Hundreds of studies have addressed the effects of tree species diversity on many forest ecosystem functions, including primary production (e.g., Liang et al. 2016). In this very active field of research, the statement that tree diversity can improve "forest ecosystem function and (associated) services" has become very common. However, the concepts of ecosystem function and ecosystem services are often confused, even though they are different in terms of their definition and relevance to scientists and managers. Whereas "function" is an ecosystem-centred concept, "ecosystem service" is human-centred (see Box 1 for definitions and an example). Focusing on function allows scientists to understand how changes in forest biodiversity can modify the key ecological processes that are driving the functioning, integrity or maintenance of forest ecosystems. Given the linkages and relationships between ecosystem functions and services, forest managers or policy makers may use such information to predict how biodiversity management or enhancement can affect the delivery of goods and services beneficial to the economy and to human well-being.

Forests generally are well-placed to deliver most of the ecosystem services (ESs) listed in current frameworks such as the Millennium Ecosystem Assessment (Millennium Ecosystem Asessment 2005) or CICES (CICES 2013), because of their wide distribution, rich biodiversity and long history of human use (see Table 1 for an overview of ESs relevant to forest ecosystems). However, empirical studies that establish quantitative and causal relationships between forest biodiversity and ecosystem services are lacking for many important ESs (Mori et al. 2017). For example, focusing only on the effect of tree 


\section{Box 1 Glossary}

\section{Ecological processes}

Ecological processes are defined as the complex interactions between the biotic and abiotic elements of ecosystems that underpin fluxes of information (e.g., stimuli), energy (e.g., sunlight) and matter (e.g., nutrients, gases, water) (Mace et al. 2012; Puydarieux and Beyou 2017). This concept is "organismscentred"; the processes involved may be physiological (e.g., photosynthesis, respiration), biological (e.g., dispersal) and/or evolutionary (e.g., selection or mutation)

\section{Ecosystem functions}

Ecosystem functions are the ecological (biological, chemical and physical) mechanisms that support the integrity or maintenance of ecosystems. This concept is "ecosystem-centred". Ecosystem functions, such as primary production or decomposition, result from interactions between ecosystem structures and processes (Ansink et al. 2008). They are not necessarily transformed into a benefit for humans. They are sometimes considered ecosystem "supporting services" (e.g., Millennium Ecosystem Assessment 2005)

\section{Ecosystem services}

Ecosystem services represent the contributions that ecosystems make to human well-being. Therefore, this concept is "human-centred". These services are defined according to their specific benefits to individuals or society. They are considered ecosystem services because they retain a connection to the underlying ecosystem functions that generate them. They are sometimes called final ecosystem services because they are outcomes from ecosystems that lead directly to goods that are valued for their contribution to human well-being (Mace et al. 2012; CICES 2013). They are typically subdivided into provisioning, regulation and cultural services

\section{Ecosystem goods}

Ecosystem goods are the products or benefits people can derive from final ecosystem services. Their value is not solely provided by ecosystems and may involve additional inputs from society, for example through human transformation or engineering. These goods may be material or immaterial, have value (monetary or otherwise) for people (Turner et al. 2000), and help to improve human well-being

\section{Human well-being}

Human well-being includes the basic requirements for satisfactory living conditions, freedom and choice, health, good social relations, and security (Millennium Ecosystem Assessment 2005). Ecosystem goods may partly fulfill these requirements.

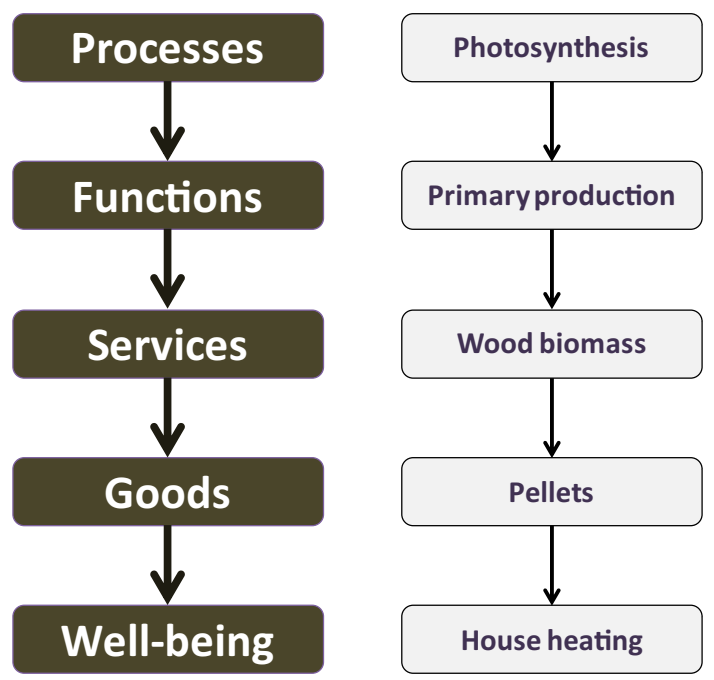

Example of dependencies between human well-being and ecological processes via ecosystem functions, services, and goods or products 
Table 1 Non-exhaustive list of ecosystem services relevant to forests, based on the CICES classification (CICES 2013), and the number of publications related to these ecosystem services that refer to mixedspecies forests according to the Web of Science (see Online Resource 1 for details)

\begin{tabular}{|c|c|c|c|}
\hline Section & Division & Class (with examples) & $\begin{array}{l}\text { Number of } \\
\text { publications }\end{array}$ \\
\hline \multirow[t]{6}{*}{ Provisioning } & \multirow[t]{2}{*}{ Nutrition } & $\begin{array}{l}\text { Wild plants (berries, mushrooms) and } \\
\text { animals (game) for food }\end{array}$ & 2 \\
\hline & & Water for drinking & 2 \\
\hline & \multirow[t]{3}{*}{ Material } & Wood biomass (fibres, wood, timber) & 416 \\
\hline & & Genetic material (for tree breeding) & 1 \\
\hline & & $\begin{array}{l}\text { Water for non-drinking purposes } \\
\text { (irrigation) }\end{array}$ & 16 \\
\hline & Energy & Fuel-wood & 4 \\
\hline \multirow[t]{11}{*}{ Regulating } & \multirow[t]{2}{*}{$\begin{array}{l}\text { Mediation of toxics or } \\
\text { nuisances }\end{array}$} & $\begin{array}{l}\text { Filtration, sequestration (by trees or forest } \\
\text { soils, of pollutants) }\end{array}$ & 24 \\
\hline & & $\begin{array}{l}\text { Mediation of smell, noise, visual impacts } \\
\text { (visual screening, noise reduction by } \\
\text { trees) }\end{array}$ & 2 \\
\hline & \multirow[t]{4}{*}{ Mediation of flows } & $\begin{array}{l}\text { Protection against erosion (landslides, } \\
\text { avalanches) }\end{array}$ & 63 \\
\hline & & $\begin{array}{l}\text { Water flow maintenance (precipitation } \\
\text { interception) }\end{array}$ & 30 \\
\hline & & $\begin{array}{l}\text { Protection against flood (by riparian forests } \\
\text { or mangroves) }\end{array}$ & 1 \\
\hline & & Protection against storms (shelter belts) & 17 \\
\hline & \multirow[t]{5}{*}{$\begin{array}{l}\text { Maintenance of physical, } \\
\text { chemical and biological } \\
\text { conditions }\end{array}$} & $\begin{array}{l}\text { Pollination and seed dispersal (by } \\
\text { pollinators or seed dispersal forest } \\
\text { species) }\end{array}$ & 111 \\
\hline & & $\begin{array}{l}\text { Habitat provision (habitat for native species } \\
\text { and endangered biota) }\end{array}$ & 817 \\
\hline & & $\begin{array}{l}\text { Pest and disease control (e.g., habitat for } \\
\text { natural enemies) }\end{array}$ & 114 \\
\hline & & $\begin{array}{l}\text { Soil formation and composition } \\
\text { (weathering, decomposition, } \\
\text { mineralization) }\end{array}$ & 307 \\
\hline & & $\begin{array}{l}\text { Climate regulation (gas and carbon } \\
\text { sequestration, temperature stabilization) }\end{array}$ & 103 \\
\hline \multirow[t]{5}{*}{ Cultural } & \multirow[t]{3}{*}{$\begin{array}{l}\text { Physical and intellectual } \\
\text { interactions with nature }\end{array}$} & $\begin{array}{l}\text { Experiential use of plants, animals and } \\
\text { settings (e.g., bird watching, hiking) }\end{array}$ & 4 \\
\hline & & $\begin{array}{l}\text { Physical use of plants, animals and settings } \\
\text { (e.g., leisure hunting) }\end{array}$ & 10 \\
\hline & & $\begin{array}{l}\text { Scientific, educational use of plants, } \\
\text { animals and settings (subject matters) }\end{array}$ & 7 \\
\hline & \multirow[t]{2}{*}{$\begin{array}{l}\text { Spiritual and symbolic } \\
\text { interactions with nature }\end{array}$} & $\begin{array}{l}\text { Emblematic or sacred plants, animals or } \\
\text { setting (sacred trees) }\end{array}$ & 19 \\
\hline & & $\begin{array}{l}\text { Existence and bequest (enjoyment of } \\
\text { wilderness, conservation for future } \\
\text { generation) }\end{array}$ & 0 \\
\hline
\end{tabular}




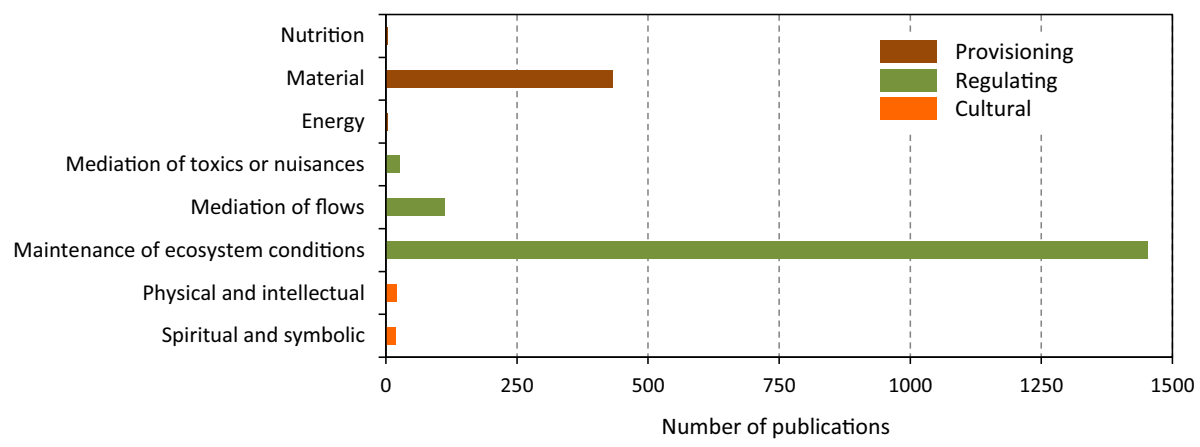

Fig. 1 Number of publications on provisioning, regulating and cultural ecosystem services referring to mixed-species forests according to a Web of Science keyword search of selected terms relating to ecosystem services (see Online Resource 1 for details)

species diversity, we found that the number of published articles (see Online Resource 1 for details on the methodology) addressing ESs provided by mixed forests was highly skewed towards provisioning services, particularly the provision of wood biomass, and regulating services such as the regulation of pests and diseases (Fig. 1). The provisioning of nutrition and energy services, and the cultural services delivered by mixed-species forests, are largely under-represented in the literature.

\section{Tree diversity effects on biomass production}

Productivity is often higher in mixtures than in monocultures, and this effect can increase with tree-species richness (Forrester and Bauhus 2016; Liang et al. 2016). A recent global meta-analysis of mixture-monoculture comparisons found that the productivity of mixtures was, on average, $26.5 \%$ greater than the mean of the respective monocultures (i.e., overyielding) and $9.8 \%$ greater than the most productive of the respective monocultures (i.e., transgressive overyielding) (this excludes very young mixtures where the effects were smaller) (Gritti et al., cited in Pretzsch and Forrester 2017). However, while productivity has often been found to increase along gradients of increasing tree-species richness, there are also instances where there is no increase, or even a decrease in productivity (Forrester and Bauhus 2016). Even when there is an increase in growth with increasing tree-species richness, it does not mean that the mixtures are always more productive than all the monocultures; it only indicates that the mean productivity of a given diversity level is greater than the mean productivity of a lower diversity level, such as the monocultures. Therefore increasing tree-species richness within a given stand will not necessarily result in greater productivity. This would require that the species interact in complementary ways, and therefore when considering specific stands (as opposed to regional patterns), species identity is likely to be more important to consider than species diversity per se.

Positive mixing effects, or complementarity effects, can result from many different processes and species interactions. These have been the subject of several reviews (Kelty 1992; Richards et al. 2010; Forrester and Bauhus 2016) and can be described as nutrientrelated, water-related or light-related interactions in addition to biotic interactions (e.g., reduced pest damage) (Forrester and Bauhus 2016). Examples of nutrient-related processes are symbiotic nitrogen fixation and accelerated rates of nutrient cycling, or where the 
abundance and composition of mycorrhizae change under mixtures leading to greater the uptake of different forms of a given nutrient (Lovelock and Ewel 2005; Richards et al. 2010). Water-related interactions include differences in rainfall interception by the canopy, transpiration, water infiltration or storage in the $\mathrm{O}$ horizon and hydraulic redistribution. Light-related interactions include differences in crown architecture and canopy structure that influence light absorption, or differences in physiology or phenology that influence the efficiency of light use and the timing of light absorption.

Many of these processes or interactions are related to stand structure or tree architecture, rather than tree species diversity per se. This is the case for most light-related interactions, many water-related interactions and a small proportion of the nutrient-related interactions (Forrester and Bauhus 2016). This suggests that many of these processes and interactions could be important in monocultures that are heterogeneous, especially uneven-aged monocultures. However, just as tree species diversity does not necessarily increase productivity, structural diversity has also been found to have negative effects on productivity, and in some forest types increasing size heterogeneity can reduce productivity by $20 \%$ (Binkley et al. 2010; Ryan et al. 2010; Stape et al. 2010; Aspinwall et al. 2011; Luu et al. 2013; Bourdier et al. 2016; Soares et al. 2016). In such stands, the heterogeneous size structure enables larger trees to acquire higher quantities of a given resource than smaller trees, which they also use more efficiently than smaller trees. The smaller trees acquire fewer resources and use them less efficiently, which has a greater negative effect on stand growth than the positive effect experienced by the larger trees (Binkley et al. 2010).

Mixing effects for any given species composition will often change along spatial or temporal gradients of resource availability or climatic conditions. In general, complementarity for a given species has been found to increase as the availability of resource "A" declines (or climatic condition A becomes harsher) if the species interactions improve the availability, uptake, or use efficiency of resource A (or interactions improve climatic condition A) (Forrester and Bauhus 2016). If soil nitrogen availability is high then any nitrogen fixed by a nitrogen-fixing species is unlikely to have much of an effect on nonnitrogen-fixing species (Forrester 2014). For example, the growth of Pseudotsuga menziesii was greater when it was mixed with the N-fixing Alnus rubra on a low-N site, but not on a high-N site (Binkley 2003) (Fig. 2a). The complementarity effect was as high as $100 \%$ and

(a)

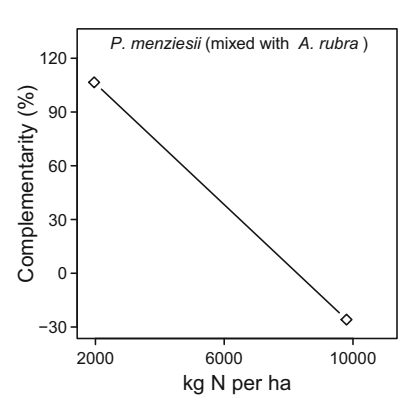

(b)

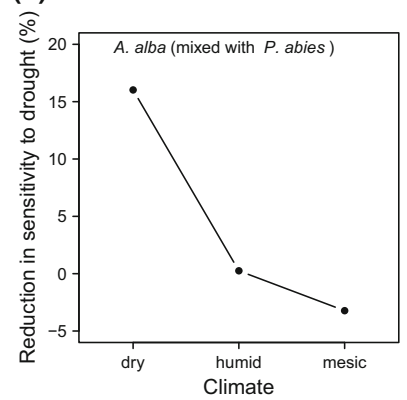

(c)

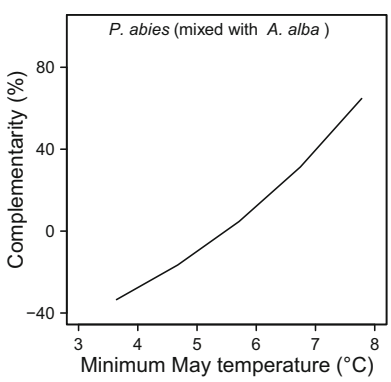

Fig. 2 Spatial changes in complementarity. Panel a shows declining complementarity for Pseudotsuga menziesii growing with the N-fixing Alnus rubra as soil N increased (Binkley 2003). Panel b shows how the relative reduction in drought sensitivity (\%) of Abies alba (mixed with Picea abies) was lower on more moist sites (Lebourgeois et al. 2013). Panel c shows increasing complementarity effects for P. abies (mixed with $A . a l b a$ ) as growing conditions improved (quantified as mean minimum May temperature) (Forrester et al. 2013) Figure modified from Forrester (2014) 
was related to greater nutrient uptake rather than changes in nutrient availability or nutrient-use efficiency. The rates of $\mathrm{N}, \mathrm{Mg}$ and $\mathrm{K}$ uptake were greater in mixtures than in $P$. menziesii monocultures at both sites, but the relative increases were much greater at the low N site (Binkley et al. 1992). The same pattern can be expected for water- and lightrelated interactions along gradients in water status or gradients in light competition, respectively (Forrester 2014). For example, the drought sensitivity (\%) of A. alba was reduced when mixed with $P$. abies but only on dry sites (Fig. 2b; Lebourgeois et al. 2013). It was suggested that this resulted in species interactions that reduced competition for water, which was expected to be more useful on drier sites or during drier periods. In mixtures where complementarity increases as growing conditions improve, interactions that improve light absorption or light-use efficiency may be important. On sites with high nutrient and water availability, stands can develop large leaf areas and competition for light may be intense. Therefore, interactions that improve light absorption or light-use efficiency can be more useful. This was suggested to have caused the increasing complementarity effect for $P$. abies when it was mixed with $A$. alba (Fig. 2c).

In conclusion, many studies have identified the processes and interactions that cause mixing effects, and much recent attention has been given to the spatial and temporal dynamics of these interactions because such information is required for most practical applications of mixtures. Important next steps are to determine when and where each individual process or interaction is likely to have the greatest effect on growth or other forest functions and whether certain processes or interactions tend to have the largest effects. This could be combined with analyses of forest inventory data to provide regionally validated information across large spatial and temporal gradients (Forrester and Bauhus 2016). Such a process-based approach could benefit from being combined with modelling studies, which can summarize much of this information while simultaneously making it readily available to foresters (Forrester et al. 2017).

\section{Habitat provisioning and effects of forest type, structure and diversity}

Globally, forest specialist species are in decline (e.g., Gregory et al. 2007), particularly those associated with primary forests containing old trees and biological legacies. There is an urgent need to identify the impacts of management on habitat provisioning in forest ecosystems and to highlight potential mitigation measures so that the range of ecosystem functions and services directly supported by biodiversity are maintained.

Most forest biota respond negatively to forest degradation and to fragmentation from pristine primary forests to small fragmented remnants. Some forest specialists tend to be more sensitive and also respond negatively to habitat conversion from native to exotic plantation forest (Farwig et al. 2008; Irwin et al. 2014; Lindenmayer et al. 2015). However, the relative habitat value of plantation forests depends upon the forest history and context within a region (e.g., Neumann et al. 2017). For example, in countries that are dominated by agricultural landscapes, exotic plantation forests may play a significant role in supporting forest biodiversity by allowing native forest specialists to use an otherwise unsuitable non-wooded landscape matrix (Berndt et al. 2008; Ruffell et al. 2017; O'Callaghan et al. 2017). Nonetheless, increasing fragmentation and loss of primary forest fundamentally alters both the species and functional composition of forested landscapes (Lindenmayer and Franklin 2002; Barnes et al. 2017). 


\section{Habitat provisioning across forested landscapes}

In fragmented forest landscapes the levels of isolation and connectivity are important factors determining habitat provisioning at this scale (Fahrig 2003). For instance, species with poor dispersal abilities, such as epiphytic lichens or small arboreal rodents, suffer significant declines in fragmented landscapes (Jönsson et al. 2017 ${ }^{1}$; Santaniello et al. 2017; Linnell et al. 2017), while the diversity of forest specialist plants in plantation forests is positively influenced by proximity to natural woodland patches providing opportunities for colonisation (Coote et al. 2013). Similarly, the amount of natural forest strongly influences the distribution of birds and bats because it provides a significant part of foraging and roosting requirements at the landscape scale (Burgar et al. 2015; Lindenmayer et al. 2015). Further, features such as hedgerows and shrubland patches form important habitat linkages facilitating movement between patches for forest invertebrates such as spiders (Oxbrough et al. 2007). By contrast, birds and bats that use both forest and non-forest habitats benefit from fragmented mosaic landscapes, and forest patchiness is a key landscape-scale resource for such species (Barbaro et al. 2012; Charbonnier et al. 2016). However, the quality of the landscape matrix itself has an effect on native bird distribution at the landscape scale, by mitigating or accelerating declines in bird species richness with increasing native habitat loss when the matrix is dominated by either wooded or nonwooded exotic habitats (Deconchat et al. 2009; Ruffell et al. 2017). Forest harvesting and the resulting interspersion of complementary habitats in the landscape mosaic is also critical to large herbivorous mammals, providing both cover and foraging areas (Côté et al. 2004; Nikula et al. 2004). However, large-scale habitat provisioning by mature and intact forests is vital for many declining forest specialists as well as for the conservation of functionally diverse forest taxa assemblages (Lindenmayer and Franklin 2002; Irwin et al. 2014).

\section{Habitat provisioning at within- and between-stands scales}

Large-scale forest management can lead to biotic homogenization of forest environments at stand and landscape scales; for example, when multispecies landscapes are replaced by even-aged monocultures, although in boreal forests the opposite effect may also occur. Diversification of tree species or age ranges either between stands in a forested landscape or within stands at a smaller scale generally enhances habitat provision for invertebrates such as arboreal beetles, and for birds and mammals (Nikula et al. 2004; Plath et al. 2012; Styring et al. 2011). Mixtures of conifers and deciduous trees may enhance biodiversity by providing habitats suitable for species associated with different tree species. For example, such mixtures may lead to greater bat species diversity through increased habitat heterogeneity and feeding resources, compared to forest monocultures (Burgar et al. 2015; Charbonnier et al. 2016). Invertebrates (e.g., spiders and beetles) and plants tend to respond more to small-scale structural changes associated with the presence of individual tree species driven by light availability and litter inputs (Chavez and MacDonald 2012; Oxbrough et al. 2016).

Diversification of age structures provides habitats for the range of species associated with each stage of the successional forest cycle and is a key driver of biodiversity. However, in tropical forests, gap-phase dynamics tend to be more important than successional cycling. Together with tree composition, stand stratification and age structure are

\footnotetext{
${ }^{1}$ This paper, published in vol. 26(11) of this journal, is a part of this Special Issue.
} 
important drivers of bat and bird diversity in forests because they directly affect their foraging (Barbaro et al. 2012; Jung et al. 2012; Phifer et al. 2017) whereas invertebrates, bryophytes and vascular plants respond more to changes in forest structure and light levels (Smith et al. 2008). Late successional stages have significant conservation importance due to their structural diversity and widespread rarity in the landscape (Lindenmayer 2017), whereas in regions that have experienced substantial loss of natural forest cover, older plantation forests can play an important role in supporting a range of native forest species (Berndt et al. 2008; Deconchat et al. 2009; Irwin et al. 2014; Ruffell et al. 2017). Primary forest and older stands provide important biological features such as habitats for flora and fauna associated with large or late successional tree species, a greater diversity of deadwood or more diverse stand structures (e.g., Burgar et al. 2015; Lindenmayer 2017; Linnell et al. 2017). However, forest ecosystems provide habitats for differing suites of species at each stage of the forest cycle. For instance, at the early stages of tree establishment a range of open habitat and generalist invertebrate and plant species coexist (Smith et al. 2008), a role which may be important in landscapes dominated by intensive agriculture with low overall biodiversity (O'Callaghan et al. 2017). Large herbivorous mammals such as moose (Alces alces) select early successional forest stages due to the availability of food resources during winter (Nikula et al. 2004), as do hen harriers (Circus cyaneus), since such habitats provide suitable ground nesting sites and an abundance of small mammalian prey (Wilson et al. 2009). Further, modern silvicultural practices such as tree planting after logging have considerably improved habitat quality for deer. Increased plant diversity provides abundant and high-quality food resources, and this contributes to problems from an overabundance of deer in many regions (Côté et al. 2004).

Deadwood is a significant contributor to habitat provision in forest ecosystems and is recognised internationally as an indicator of forest health. Deadwood tends to be more abundant in old growth or less managed stands (except in tropical forests) and provides both habitat and forage for a large suite of the forest biota (Seibold et al. 2015). Many forest bird and mammal species depend on the presence of tree cavities associated with deadwood for nesting and roosting (Cockle et al. 2011; Burgar et al. 2015). Saproxylic fungi, plants and invertebrates respond to changes in deadwood characteristics including volume, size classes, situation and decay stage, which provide variety in habitat structure and available food sources at differing stages of the decomposition process (Seibold et al. 2015). For instance, wood-boring invertebrates may initially colonise early decay stage wood, providing mechanisms for fungi to enter and enhance the decomposition process for later successional species (Ulyshen 2016).

\section{Knowledge gaps and future challenges}

Forest ecosystems support a large proportion of species threatened with extinction, and more applied research is urgently needed to evaluate sustainable forest management practices that will contribute to the protection of threatened species. The diversity of forest structure and composition need to be maintained at landscape and regional scales as a spatial insurance to provide habitats for a large suite of specialist forest species. Habitat provisioning by forests for multiple taxa and trophic levels is a key ecosystem service, which in turn positively influences forest ecosystem functioning through a range of mechanisms (Barnes et al. 2017; Lindenmayer 2017). There is also a need for increased public and political support for sustainable forest management to reduce species losses. The impacts of large-scale forest harvesting, thinning and replanting with exotic species on habitat provisioning on well-known groups of mammals, birds and plants are relatively 
well-investigated using basic community-level metrics (e.g., species richness, abundance, species composition). However, for less charismatic groups such as some invertebrates and fungi, and for more complex community interactions and ecosystem functions, as well as longer-term impacts like climate change, the effects of forest management and mitigation measures remain largely unknown and present a significant future research challenge. This is particularly relevant for the biota associated with forest canopies and the flora and fauna of tropical forests, where the impacts of forest fragmentation and modern forest practices remain largely unknown despite these forests' high conservation value and their considerable role in the provision of ecosystem services.

\section{Pollination and forest diversity}

Animal pollination, which is fundamental to the reproduction and persistence of most flowering plants, is an important ecosystem service (Millennium Ecosystem Assessment 2005). As biodiversity contributes to various ecosystem processes, functions and services, the declining diversity and abundance of pollinators (mainly insects and birds) has raised concerns about the effects on both wild and crop plants (Potts et al. 2010). Experimental evidence indicates that greater pollinator diversity results in improved seed production in plants (Fründ et al. 2013). Furthermore, it has also been shown that pollinator species richness per se is not as important as the diversity and complementarity of functional traits of pollinators, such as different plant species and ambient temperature preferences (Fründ et al. 2013).

In agricultural ecosystems, pollination services are provided by numerous species of wild insects and vertebrates, as well as some managed species that also rely on wild ecosystems for nesting and food resources (Garibaldi et al. 2013). Approximately 75\% of the world's leading food crops, such as cacao and oil palm in the tropics and almonds and apples in temperate regions, depend at least in part on animal pollination for yield and/or quality (Klein et al. 2007). The economic contribution to the current global crop production attributed to animal pollination is estimated to have an annual market value ranging between US\$235 billion and US\$577 billion (Potts et al. 2016). Diversified farming systems such as mosaic agricultural landscapes with forest remnants and agroforestry are more effective than large agricultural monocultures in providing nesting and floral resources for pollinators and in sustaining pollinator populations and communities throughout the year (Fahrig et al. 2015). The conservation of natural ecosystems such as forests, which may provide habitats for pollinators, is crucial, and the distance from these habitats to farms affects the success of seed and fruit set (Kennedy et al. 2013).

In terrestrial ecosystems other than agricultural systems, it is estimated that over $85 \%$ of wild flowering plants globally are reliant to some degree on animals to transfer pollen (Ollerton et al. 2011). The wide variety of pollinator species contributes to the successful pollination of wild plants, and many flowering plants and their pollinators have close coevolved relationships (Proctor et al. 1996). Greater diversity of pollinator species and functional groups generally enhances the success of pollination services (Tylianakis et al. 2008). Local pollinator loss can be a serious threat to plants that are dependent on certain pollinators, potentially causing their eventual extinction. Empirical studies in forest landscapes showed negative correlations between pollination success in wild plants and the extent of loss and fragmentation of forest remnants (Aizen and Feinsinger 1994). Although the economic value of pollination of wild plant species has not been quantified, it is certain 
that it contributes substantially to the provision of food, habitats and other resources for a wide range of organisms.

Tree types and human management of forests affect pollinators and pollination services. Planted forests that consist of one tree species, grown as even-aged monocultures and intensively managed, may result in reduced diversity and abundance of pollinators compared with natural forests that have greater structural and plant species diversity (Taki et al. 2011). However, there are cases where active management of planted forests results in positive effects on pollinators. For example, thinning trees may enhance the diversity and abundance of pollinators in planted forests (Taki et al. 2010). Even clear cutting and other disturbances of planted forest that create open environments that are preferred by early successional species that can act as pollinators (Rubene et al. 2015; Taki et al. 2013). Moderate levels of human disturbance of forest ecosystems and anthropogenic land use may result in greater bee abundance and species richness (Winfree et al. 2007). However, some pollinator species such as honeybees and stingless bees use old growth forest for nesting in cavities in large trees (Michener 2007).

Maintaining the quantity and quality of natural or semi-natural forest ecosystems across the landscape is important to conserve and restore habitats for pollinators. Retaining habitats within a landscape helps to safeguard an essential level of pollination services for both agricultural and forest ecosystems. Beyond the landscape scale, habitat conservation and restoration at the local scale are also necessary to provide nesting and feeding resources for pollinators (Taki et al. 2017). However, there are still gaps in our knowledge about how landscape and local scale management of forested ecosystems can be integrated for the best outcome for pollinators and pollination services.

\section{Biodiversity and seed dispersal}

Seed dispersal by mammals is a major factor in maintaining tree community structure over the long term in tropical forests (Seidler and Plotkin 2006) and is a key mechanism that explains the pattern of low aggregation of conspecifics on tropical forest plots. Evidence also suggests that tropical forests deprived of seed-dispersing animals exhibit replacement of fruiting trees by species with wind seed dispersal (Brodie and Aslan 2012). While the seeds of many tree species are dispersed by wind, others are dispersed by herbivores and frugivores (a process known as zoochory), especially in tropical forests. In Mexico, CortesFlores et al. (2013) found that $68 \%$ of tree species were dispersed through zoochory. Reduced or absent populations of seed-dispersing animals result in poor to no dispersal, especially of large-seeded trees that depend on large animals such as elephants (AnzuresDadda et al. 2011; Brodie and Aslan 2012; Beaune et al. 2013). Some animal species play important co-evolved and complementary roles in maintaining plant communities (Gonzalez et al. 2009; Garcia and Martinez 2012; Gonzalez-Varo et al. 2013). The rate of seed germination for some species is enhanced by passage of seeds through mammalian guts (endozoochory) (Traveset 1998; Campos-Arceiz and Blake 2011). Absence of dispersal processes results in a homogenisation of forest plant species and has long-term consequences for forest structure and other ecosystem services (Terborgh et al. 2008; Lehouck et al. 2009; Markl et al. 2012). Proximity of seed sources affects seed dispersal processes to adjacent areas, so habitat connectivity can improve the influx of animal-dispersed seeds (Lehouck et al. 2009; Jesus et al. 2012). Animal species that simply drop seeds have effective distances of generally under $0.5 \mathrm{~km}$ (Wehncke and Dominguez 2007) but 
dispersal distances by seed-eaters are often many kilometres (Beaune et al. 2013). Hence, the loss of seed dispersers and their habitats ultimately produces a decline in local or regional tree species richness (Lehouck et al. 2009; Beaune et al. 2013; Bueno et al. 2013).

\section{Resistance to wind storms}

Wind is a major disturbance agent in all forests (Payn et al. 2015) and a key part of the dynamics of many natural forest ecosystems, particularly temperate forests (Ulanova 2000; Wolf et al. 2004). However, wind damage can have large economic, environmental and social impacts on managed forests and the societies that depend on them (Gardiner et al. 2013). Therefore, mitigating the impact of wind damage in such forests is a way to help maintain the important ecosystem services that managed forests can provide to society.

Natural forests are remarkably resilient to major damaging events such as storms and hurricanes (Cooper-Ellis et al. 1999) and it is possible that the mixed structure and mixed species of such forests contribute to both their resistance and resilience. However, very little is known about the processes involved in wind damage and recovery in natural forests and it has proven necessary to investigate the behaviour of managed forests to understand the functioning of natural forests in response to wind damage (Everham III and Brokaw 1996). For example, there is evidence that wind damage to managed forests can be reduced by the use of multiple species and variable forest structures, for a number of reasons. Firstly, there are differences between species in the level of resistance to wind damage (Hanewinkel et al. 2013) and the overall stability of a forest can be enhanced by using more resistant species to provide a framework. Secondly, more stable species can help stop damage propagation during a storm, which occurs when an unstable or weak tree is damaged and creates a gap in the forest, increasing the wind loading on the remaining trees and leading to further damage (Dupont et al. 2015). Thirdly, in systems with a mixture of species, the slower growing species may die and act as a self-thinning system that removes the dangers of normal thinning where the canopy is opened up and increases the wind loading on the remaining trees (Quine and Malcolm 2007). Fourthly, there is evidence that wind loading on broadleaves is reduced in the winter, which is the period with the strongest winds, because they lose their leaves and have reduced overall drag (Bonnesoeur 2016), so an admixture of broadleaves could be beneficial to overall stand stability. Fifthly, when the canopy is multi-storied because of age and species variation, the momentum absorption from the wind appears to take place over a greater depth of the canopy and measurably reduces the wind loading on the tallest trees (Gardiner et al. 2005). Finally, multi-storied forests are less at risk following harvesting of the tallest trees, for example, in a single-tree selection system, or if individual trees start to blow down in a storm, because the understorey trees are smaller and will experience lower wind loading even when gaps are created.

Based on the discussion above it is probable that natural forests are more resistant and more resilient to wind damage because of their mixed structure due to variations in age and species. Therefore, managed forests that more closely mimic natural forests are almost certainly more resilient than even-aged stands, will recover more quickly after a damaging event, and ecosystem services from the forest will be restored more rapidly. In addition, mixed species and age stands will require less technical and financial input to recover after storm damage (Stanturf et al. 2007) because the understorey trees will be able to grow into the space previously occupied by the damaged trees and less intervention will be required. 
Therefore, by having a mixture of species and tree ages it is possible to have a forest with high biodiversity and compositional structure, as well as one that is more resistant and resilient to wind disturbance. However, it must be remembered that resilience in forests is a dynamic process, and following a large wind disturbance a forest will be different and so will be the level of ecosystem services it can provide.

\section{Fire regulation and mitigation}

Fire is an essential process in the natural dynamics of some ecosystems, and a potential selection force behind the current distribution of vegetation types worldwide (Bond and Keeley 2005). Although fire can diminish the well-being of people and drastically reduce ecosystem services, fire is a natural process in many ecosystems, and it is not necessarily a negative element per se. The maintenance of a natural fire regime is often required to sustain or even enhance the productivity of ecosystems that have coexisted, or even coevolved, with a specific fire regime (Brockway et al. 2002). Therefore, the impact of fire on a forest and its associated ecosystem services can be either positive or negative, depending on the forest type, the fire regime, and the ecosystem services (Thom and Seidl 2016).

However, it is also recognized that global change (climate change, population growth, change in land use practices, or even an increase in fire suppression efforts) has modified fire regimes worldwide, causing an increase in the frequency of large catastrophic fires and an associated decrease in the supply of ecosystem services (Schröter et al. 2005). In addition to the negative influence of large fires on a number of ecosystem services, such fires also have a direct and negative impact on the well-being of humans, due to air pollution, cost of suppression activities, and loss of property and human lives. In this context, fire risk mitigation, aiming to reduce the frequency and impact of catastrophic fires, and fire regulation to maintain a desirable fire regime, can be considered ecosystem services themselves.

Fire regulation and mitigation require the maintenance of a certain fuel load and spatial continuity of fuels, using active management to reduce the risk that fire can impose on ecosystem services, while maintaining those ecosystem processes and services that depend on fire (Sturtervant et al. 2009). In this sense, forest biodiversity is often overlooked, unless one considers the clearance of trees and shrubs in the lower forest strata to mitigate fire risk as a strategy that influences biodiversity. Even though the impact of fire on biodiversity, either positive or negative, has been frequently addressed, the impact of species diversity on fire mitigation and regulation is usually neglected.

It is assumed that a diverse landscape will help to modify fire behavior, minimize negative impact, and create more resistant and resilient landscapes and ecosystems (Fernandes et al. 2010). However, what applies to large-scale landscapes is not always true at the stand level. When considering the impact of increasing diversity on fire behavior and forest resistance, we have to assume that individual trees' resistance to or survival capacity in a fire of a given intensity and duration depends on the capacity of each tree to protect sensitive tissues (Dickinson and Johnson 2004). This capacity is defined by each tree's size and species. Mixing the right set of species in a stand may have a positive impact on tree growth — one of the desirable traits for resisting fires—but may also result in more continuous fuel supplies, leading to more intense fires. The limited number of studies that have analysed the impact of species composition and level of mixture on fire behavior and tree 
mortality have all identified higher resistance in conifer-broadleaf mixtures compared to pure conifer stands. Forest stands composed of broadleaved trees are usually more resistant to fire, even when pure, mainly due to their lower flammability and their resprouting capacity. Therefore, the impact of increasing species diversity on stand resistance should take into account the capacity of each species to resist fire, and the potential changes in fire behaviour caused by modifications of the forest and the fuel supply structure (González et al. 2006, 2007).

Reducing fire intensity and increasing forest resistance are, in most cases, achieved by the same management approaches, which aim to reduce the negative impact of fire on most ecosystem services and minimize the direct impact of fire on human well-being. However, when considering the long-term impact of fire on ecosystem services, the resilience of forest stands cannot be overlooked. Functional traits defining the resistance or resilience of trees to fire are often species-specific (Bond and Midgeley 1995), especially in conifers. Mixing species with different traits may limit the resistance of a forest due to changes in fire regimes, but at the same time allow a faster post-fire recovery of the vegetation cover (Martín-Alcón et al. 2015) and the associated ecosystem services.

In conclusion, the use of forest diversity as a means for fire mitigation and/or regulation needs to consider the spatial nature of fire. Generating a diverse and fragmented landscape, consisting of a mosaic of different forest types and land uses, is a clear strategy for minimizing the negative impacts of fire, inside and outside the forest. However, selecting a forest typology for mitigating fire is not a straightforward decision at the stand level. Any decision regarding forest composition and management should consider the fire regime (real or emulated) that is expected or will be regulated. It should also consider the response of the tree species to such fire regimes, according to their functional traits, and in the case of mixtures, the compatibility between species and traits. Finally, trade-offs between responses to fire and impacts on ecosystem services should be evaluated in order to efficiently manage different forest typologies. In general, the impact of mixing species on a stand's post-fire resistance has been poorly studied, or oversimplified. Past studies are scarce, local, and often based on broad species groupings (such as conifers and broadleaves). Further research is required to identify which species have compatible functional traits for inducing enhanced fire resistance, including an assessment of the combined accumulation and structure of living and dead fuels. Other aspects that call for further research include the impact of mixing species on forest humidity and fuel moisture, and the non-additive effect of mixing different fuels on flammability.

\section{Effects of forest tree diversity on pest regulation of native and invading insects}

Insect damage can have major impacts on forest ecosystem functioning (Boyd et al. 2013). For instance, bark beetle outbreaks causing large-scale mortality have been observed to shift forests from carbon sinks to carbon sources (Kurz et al. 2008). Even minor chronic damage such as background defoliation (Kozlov et al. 2015) may result in significant growth loss in trees (Zvereva et al. 2012).

Although it is a common belief among foresters that forest monocultures are more susceptible to pest outbreaks and insect invasions than mixed forests, it has only recently been demonstrated, via meta-analyses, that tree species grown in pure stands are, on average, significantly more affected by insect herbivory than the same species grown in 
mixed stands (Jactel and Brockerhoff 2007; Castagneyrol et al. 2014a; Guyot et al. 2016; Jactel et al. 2017). This phenomenon has been termed 'associational resistance' (Barbosa et al. 2009). However, most stand-scale studies involved native insects, and there is comparatively little information on invasions by non-native insects. Two studies in Europe have shown negative relationships between tree species richness and the abundance of invasive tree-feeding insects at the plot or stand scale (Jactel et al. 2006; Guyot et al. 2015). Conversely, in the USA, a positive relationship between native tree species richness and the number of successful invasions by non-native tree-feeding insects was observed (Liebhold et al. 2013), although that study assessed larger-scale county-level data that are not directly comparable with plot-level data.

While forest insect damage has been found to decrease along gradients of tree diversity in temperate forests (Guyot et al. 2016), tree species composition appears to be more important than tree species richness per se in explaining diversity-resistance relationships in forest ecosystems. In particular, the likelihood of associational resistance increases with the functional dissimilarity of associated trees in mixed forests (Castagneyrol et al. 2014a). This would explain why there is weak evidence for better resistance of pure stands composed of several genotypes of the same species compared to single-genotype monocultures (Moreira et al. 2014; Barton et al. 2015).

Three main ecological mechanisms are proposed to explain why pest regulation is more effective in mixed forests. The first mechanism relates to the density of host trees, which is proportionally reduced in forests where host and non-host species are 'associated' compared to pure forests of host trees. The resource concentration hypothesis (Root 1973) predicts that herbivores are less likely to find, remain and feed on their host trees when they are less numerous and scattered amongst non-host trees in mixed stands (Sholes 2008). This mechanism mainly occurs at the patch ('stand') level (Hambäck and Englund 2005), depending on the ability of herbivores to perceive the overall quality of the patch, thus influencing patch immigration and residence rates (Verschut et al. 2016).

The second mechanism relates to the ability to locate and exploit individual host trees, depending on the frequency and identity of host and non-host trees. Non-host trees may reduce the visual apparency (Castagneyrol et al. 2014b) and chemical apparency (Jactel et al. 2011) of host trees, making them more difficult for insects to find. Neighbouring trees from other, associated species may also be preferred by insect herbivores, leading to a diversion process that benefits the focal tree species (Jactel et al. 2005). This mechanism thus occurs within a patch (or 'stand'), depending on insects' movement between resources, resource perception and dietary preferences (Hambäck and Englund 2005; Verschut et al. 2016). Both mechanisms involve plant-herbivore interactions and are more effective against specialist insect herbivores (monophagous) than generalists (polyphagous) (Castagneyrol et al. 2014a). In some cases, generalist pests may even cause more damage in mixed forests (associational susceptibility, e.g. Schuldt et al. 2010) as a result of spill-over onto less preferred neighbouring species after the depletion of the favoured host tree species (White and Whitham 2000), or because of the potential benefits of dietary mixing (Unsicker et al. 2008).

The third mechanism involves plant-herbivore-predator interactions and is related to the 'enemies hypothesis' (Root 1973). This states that more diverse forests can provide more diverse and abundant feeding and nesting resources for insect predators and parasitoids, thus increasing their capacity to control populations of prey (i.e., insect herbivores). Although an increasing body of evidence supports a positive correlation between tree diversity and natural enemy diversity (Castagneyrol and Jactel 2012; Staab et al. 2014), the 
actual contribution of predators to the top-down control of pest insects in mixed forests remains difficult to demonstrate (Jactel et al. 2006; Muiruri et al. 2016).

All three mechanisms are likely to affect non-native invading insects, and they would be expected to mitigate invasions of species-rich forests to some extent. Conversely, because most tree-feeding insects are relatively host-specific, an unavoidable consequence of greater tree diversity is that it leads to an increase in the number of host trees that may be colonised by potential invaders (Liebhold et al. 2013). Ultimately, the extent of realised invasions depends on the combined net effect of negative and positive effects of tree species richness.

The spatial extent of pest regulation services exhibits a nested pattern. While reduced individual tree damage is probably strongest at the scale of neighbouring trees, for example due to reduced host apparency (Guyot et al. 2015; Damien et al. 2016), improvement of forest health can be achieved at the stand scale (Guyot et al. 2016). Improved effectiveness of biological control by natural enemies may also provide benefits to adjacent land uses such as agricultural crops (Veres et al. 2013).

The temporal dimension of forest diversity-pest regulation relationships remains the main knowledge gap. On the one hand mixed-forest dynamics are triggered by differences in tree species-specific growth rates, which may lead to changes in host apparency (e.g., Damien et al. 2016) and perhaps host palatability. These factors may change the magnitude and direction of effects on pest insects in the forestry cycle. On the other hand, insect populations have their own dynamics, sometimes with eruptive or cyclic outbreaks, but little is known about whether diversity effects could vary depending on herbivore and predator abundance (Fernandez-Conradi et al. 2017). As a consequence, there is a need for long-term studies testing the influence of tree diversity on the population dynamics of forest insects and estimating the resilience of mixed forests to pest outbreaks.

The pest regulation service provided by forest biodiversity is thus intimately linked with two main ecosystem functions: primary production (which controls for tree apparency and trade-offs with plant defences) and biotic interactions (e.g., predator-prey interactions). Increasing tree species diversity is likely to result in more complex forest structure and composition, thus providing more habitat for predators and parasitoids that may regulate pest populations through top-down biotic interactions. Bottom-up biotic interactions are also influenced by tree species diversity via both the relative abundance of host vs. nonhost tree species for insect herbivores and the diversity of their traits, such as growth pattern and secondary metabolism, which ultimately influence the probability of host trees being found, colonized and damaged (Table 1). Pest regulation may have benefits for several forest goods and products. Pest damage reduction ultimately results in more wood biomass of better quality and also helps maintain forest cover, thus regulating air and water quantity and quality, preventing soil erosion, and improving the beauty of forest areas used for recreational activities.

\section{Biodiversity and carbon sequestration in forests}

Carbon in forests is sequestered through photosynthesis, and so is directly related to the species level of biodiversity, as follows. Carbon is stored in five distinct pools in forests: above-ground and below-ground live biomass, in deadwood including snags, litter, and soil. Carbon in forests is a function of forest productivity (see above), but the question of the relationship of biodiversity to carbon storage differs somewhat from sequestration. In 
part this difference occurs because different tree (and plant) species have different wood densities, different rates of photosynthesis and respiration, and because decomposition occurs at different rates, depending on multiple factors. Therefore, in most studies, the functional characteristics and richness of plant communities are major drivers of carbon accumulation in all pools (Kirby and Potvin 2007; Conti and Diaz 2013; Harmon et al. 2013; Lange et al. 2015), although Finegan et al. (2015) found no relationship between species richness and biomass. For soils, Lange et al. (2015) found that elevated carbon storage at sites with high plant diversity is directly related to the soil microbial functional community (i.e., soil biodiversity), which in turn is related to plant species richness, suggesting that soil carbon storage is mainly limited by the integration of new carbon into soil and less by the decomposition of existing soil carbon. In many studies in tropical forests, planted forests and second growth forests-which often lack species with high wood density, and generally have lower taxonomic diversity than primary forests - there is typically lower biomass stored in live and dead biomass pools (Cavanaugh et al. 2014; Gonzalez et al. 2014; Osuri et al. 2014; Shirima et al. 2015). Single species plantations result in reduced litter, or recalcitrant litter, followed by depletion of soil biodiversity and as a consequence less stored soil carbon (de Vries et al. 2013; Zhao et al. 2013; Aslam et al. 2015).

\section{Cultural ecosystem services in forest ecosystems}

Cultural ecosystem services (CESs) are defined as ecosystems' contributions to the nonmaterial benefits that arise from complex and dynamic relationships between ecosystems and humans (Chan et al. 2012; Fagerholm et al. 2012). These services are often intangible, making them difficult to measure (Daniel et al. 2012). Commonly recognized CES categories include: cultural diversity and identity, spiritual and religious values; knowledge systems, including education; inspiration; aesthetic values; cultural heritage values; and recreation and ecotourism (Costanza et al. 1997; Millennium Ecosystem Asessment 2005). The emphasis on CES benefits is heavily influenced by a country's cultural, social, economic and political organisation. Populations in societies with access to surplus wealth and leisure time frequently emphasize the importance of aesthetic values, recreation and tourism (Millennium Ecosystem Asessment 2005). In contrast, indigenous peoples often express the importance of CES benefits relating to cultural identity and heritage, kinship, and knowledge integrity and transfer (Pert et al. 2015; Boafo et al. 2016; Sangha and Russell-Smith 2017).

The global significance of forests to humans means CESs are deeply ingrained in the value-belief systems of many societies. Indigenous forest peoples in particular have a complex matrix of values that shape and guide their attitudes, beliefs and relationships with the forests in which they live (Rickenbach et al. 2017). Since the majority of forests worldwide are populated and used by humans (Forest Peoples Programme 2017), the biodiversity contained within these ecosystems contributes extensively to the provision of CES benefits. For example, indigenous peoples commonly link forest landscapes and biodiversity to tribal identities, association with place, kinship ties, customs and protocols, stories, and songs (Gould et al. 2014; Lyver et al. 2017a, b). Spatial patterns of CES identified by rainforest Aboriginal peoples in Australia were related primarily to variations in social structures (e.g., adherence to cultural protocols), rather than to ecological attributes such as forest biodiversity patterns (Pert et al. 2015). 
In developed nations the aesthetic value of forest landscapes has featured strongly in CES assessments of forests. For example, peoples' judgements of scenic beauty in forests of the north-western USA were greater in areas where more green trees were retained by logging companies, provided the retained trees were evenly dispersed across the landscape rather than clumped in small groups (Ribe 2005). Similarly, the Black Wood of Rannoch is one the largest remnants of ancient Caledonian pine forest in Scotland and contributes significant CES values, such as aesthetic and spiritual benefits (Edwards et al. 2016). In East Germany, forests are considered a 'hot-spot' for CES in regard to education (learning about biodiversity), spirituality and recreation (e.g., hiking-Plieninger et al. 2013). However, biodiversity in these forests also contributes a cultural ecosystem 'disservice' as local people have a fear of roaming wolves (Plieninger et al. 2013). Recreation and tourism are by far the most commonly mapped CESs in forest-related assessments, largely because of the ease with which economic-based values can be measured, although estimates can vary widely. An assessment of recreational services provided by forests in North Zealand, Denmark, varied from 5200 to 14,850 EUR/ha/year for forests with the highest per hectare value, and from 200 to $320 \mathrm{EUR} / \mathrm{ha} / \mathrm{year}$ for forests with the lowest per hectare value (Zandersen and Termansen 2012). In northern Italy, tourism contributed almost $10 \%$ of the total economic value of ecosystem services for the forests of the Fiemma and Fassa Valleys (Häyhä et al. 2015). While recreation and tourism values are critical for many local economies, rising human populations in some countries are increasingly placing pressure on forest resources and the quality of other non-monetary cultural services (Wear and Greis 2002).

While CESs are a vital part of the ecosystem services complex, they are, on the whole, under-researched. Intangible and non-negotiable CES benefits continue to challenge valuation methods and processes. New valuation tools and frameworks that can reliably account for non-material CES benefits need to be developed and tested. Linking environmental conditions with human wellbeing was a common concept that emerged from the MEA process (Millennium Ecosystem Assessment 2005). Research that explores shared CES concepts between user groups and maps the diversity of CES benefits is therefore needed to assist in conflict resolution (e.g., between tourists and indigenous peoples), especially as activities like recreation and tourism expand globally (e.g., Fagerholm et al. 2012). New frameworks that can consider the full range of CES benefits associated with forest biodiversity will result in solutions and trade-offs for real-world issues to accommodate different sectors of societies. These frameworks can "foster new conceptual links between alternative logics" (i.e., alternative belief systems) "relating to a variety of social and ecological issues" (Milcu et al. 2013). Research that supports the mapping of indigenous peoples' CES to themes relevant to them will help prevent their values being overlooked or becoming institutionalized in current frameworks.

\section{Forest biodiversity, multifunctionality and trade-offs among ecosystem services}

Forests are valued for multiple ecosystem services, including timber production, climate regulation and recreation, and for biodiversity in its own right (Mace et al. 2012). A major challenge for forest managers is to maximise as many of these services as possible, thereby maximising 'ecosystem multifunctionality' (Hector and Bagchi 2007). When different ecosystem services and biodiversity are all positively related to each other, meeting this 
goal is, at least in theory, relatively straightforward. However, in recent years, a number of studies have investigated relationships between forest ecosystem services and found that while some ecosystem services correlate positively, others show strong negative relationships at local scales (Chhatre and Agrawal 2009; Gamfeldt et al. 2013; Van der Plas et al. 2016a; Lutz et al. 2016) or large spatial scales (van der Plas et al. 2017). Because of these trade-offs, maximising all desired forest ecosystem services is challenging.

Some trade-offs between ecosystem services occur because different tree species provide different ecosystem functions and services (Gamfeldt et al. 2013; van der Plas et al. 2016a), while others are driven by forest management, which often maximises certain ecosystem services at the cost of others (Chhatre and Agrawal 2009; Verkerk et al. 2014). Hence, at local scales, promoting certain tree communities may maximise some, but not all, ecosystem services of interest. As a result, forest ecosystem multifunctionality generally increases with both tree (Gamfeldt et al. 2013; van der Plas et al. 2016a; Ratcliffe et al. 2017) and fungal (Mori et al. 2016) species diversity, although it is almost impossible to maximise all desired ecosystem services and functions underpinning them at local scales (Ratcliffe et al. 2017). Therefore, recent studies have investigated whether larger-scale biodiversity, caused by a high spatial turnover in species composition (i.e. high betadiversity) can promote ecosystem multifunctionality at the landscape scale. This has turned out to be the case, as a high beta-diversity ensures that different localities complement each other in the ecosystem functions and services they provide (Mori et al. 2016; van der Plas et al. 2016b).

Because of the large amount of data that is required for research on biodiversity and ecosystem multifunctionality, this field has only taken off relatively recently. Hence, despite many recent advances, there are still many unresolved questions regarding how biodiversity and ecosystem multifunctionality can be simultaneously maximised in natural forests. For example, it is unknown whether the positive effects of local-scale tree species richness on ecosystem multifunctionality are even stronger when co-occurring species differ significantly in their traits or evolutionary origins, although such information can be crucial for planting multifunctional forests. In addition, it is known that forests can provide multiple ecosystem services to neighbouring landscape units, such as agricultural fields (Mitchell et al. 2014). However, whether the benefits of diverse forests for neighbouring fields are greater than those of species-poor forests is still an open question. With the increasing interest in understanding what drives multifunctional landscapes, it is likely that these and other related questions will be investigated in the future.

\section{Conclusions}

Our review confirms that forest type and tree species richness affect forest biodiversity and that forest diversity can be an important factor in ecosystem function and the provision of ecosystem services. However, while there are clear mechanisms by which tree diversity can improve ecosystem function and the delivery of ecosystem services, for many ecosystem services, there is still uncertainty about the extent of a 'functional relationship' between biodiversity and the provision of those services. We also need to better evaluate the effect of different levels of tree diversity; not only species but also genetic and functional diversity. And while canopy trees are obviously a dominant feature of forests, the diversity of understorey plants, vertebrates, invertebrates, fungi and microbes is also likely to be important for ecosystem services. Furthermore, many ecosystem services 
remain comparatively poorly studied in forests in relation to biodiversity; this applies particularly to cultural services but also to some provisioning services (see Table 1 and Fig. 1). There is clearly a need for more research in this area to enable evidence-based advice for forest management and policy to enhance the provision of ecosystem services (see also Mori et al. 2017).

For natural forests this discussion may seem somewhat academic, as it is unlikely that tree species composition and diversity would be altered substantially in the interest of ecosystem services. Nevertheless, it is important to raise awareness about the role of natural forests and forest diversity in the provision of ecosystem services to highlight their value beyond the provision of timber and recreation. However, for planted forests there is ample opportunity for optimising their composition and diversity because replanting after harvesting is a recurring process. If it can be shown that there are opportunities for adding value and for increasing the resistance or resilience of planted forests, these should be good incentives for forest owners and managers to consider alternatives to the monoculture paradigm of most planted forests. We thus endorse the plea of Paquette and Messier (2010) "for the implementation of well-conceived, diverse, multi-purpose [forest] plantations as a way to conserve forest biodiversity and ecosystem functions".

The relevance of forest ecosystem services does not stop at the forest edge. There is much scope for synergies between forests and farming land uses; for example, even small patches of forest can benefit crop production by enhancing pollinator and natural enemy populations, although they may also provide disservices (Decocq et al. 2016). Adding planted forests to catchments dominated by dairy farming reduces greenhouse gas emissions and improves water quality (Monge et al. 2016). These are also important considerations in the debate about land sharing vs. land sparing. Clearly, any afforestation plans should carefully consider previous land use in terms of the likely biodiversity and conservation outcomes (e.g., afforestation of degraded farmland vs. natural grassland or forest). Finally, any planted forest plan should evaluate options for mixed-species forests (Pretzsch et al. 2017) as these are likely to provide a wider range of ecosystem services.

Acknowledgements We are indebted to numerous colleagues for invaluable discussions about forest biodiversity and ecosystem services. We thank the International Union of Forest Research Organisations (IUFRO) for facilitating the IUFRO Task Force 'Contribution of Biodiversity to Ecosystem Services in Managed Forests'. Many thanks also to Judy McDonald for edits and comments on the manuscript. EGB acknowledges support from the New Zealand Ministry of Business, Innovation and Employment (MBIE) via core funding to Scion (C04X1104) and contestable funding (C09X1307) to the 'BEST' programme. Contributions by JRG were funded by the Ministerio de Economía, Industria y Competitividad (RYC-201108983) and the CERCA Programme/Generalitat de Catalunya. HT was supported by the Ministry of Agriculture, Forestry and Fisheries, Japan, and the Ministry of the Environment, Japan (Environment Research and Technology Development Fund S-15-2).

\section{References}

Aizen MA, Feinsinger P (1994) Forest fragmentation, pollination, and plant reproduction in a Chaco dry forest, Argentina. Ecology 75:330-351

Ansink E, Hein L, Hasund KP (2008) To value functions or services? An analysis of ecosystem valuation approaches. Environ Values 17:489-503

Anzures-Dadda A, Andresen E, Martínez ML et al (2011) Absence of howlers (Alouatta palliata) influences tree seedling densities in tropical rain forest fragments in southern Mexico. Int J Primatol 32:634-651

Aslam TJ, Benton TG, Nielsen UN, Johnson SN (2015) Impacts of eucalypt plantation management on soil faunal communities and nutrient bioavailability: trading function for dependence? Biol Fertil Soils 51:637-644 
Aspinwall MJ, King JS, McKeand SE, Bullock BP (2011) Genetic effects on stand-level uniformity and above- and belowground dry mass production in juvenile loblolly pine. For Ecol Manag 262:609-619

Balvanera P, Pfisterer AB, Buchmann N et al (2006) Quantifying the evidence for biodiversity effects on ecosystem functioning and services. Ecol Lett 9:1146-1156

Barbaro L, Brockerhoff EG, Giffard B, van Halder I (2012) Edge and area effects on avian assemblages and insectivory in fragmented native forests. Landsc Ecol 27:1451-1463

Barbosa P, Hines J, Kaplan I, Martinson H, Szczepaniec A, Szendrei Z (2009) Associational resistance and associational susceptibility: having right or wrong neighbors. Annu Rev Ecol Evol Syst 40:1-20

Barlow J, Gardner TA, Araujo IS, Perez CA et al (2007) Quantifying the biodiversity value of tropical primary, secondary, and plantation forests. Proc Natl Acad Sci USA 104:18555-18560

Barnes AD, Allen K, Kreft H, Haneda NF et al (2017) Direct and cascading impacts of tropical land-use change on multi-trophic biodiversity. Nat Ecol Evol. doi:10.1038/s41559-017-0275-7

Barton KE, Valkama E, Vehviläinen H, Ruohomäki K, Knight TM, Koricheva J (2015) Additive and nonadditive effects of birch genotypic diversity on arthropod herbivory in a long-term field experiment. Oikos 124:697-706

Bauhus J, van der Meer P, Kanninen M (eds) (2010) Ecosystem goods and services from plantation forests. Routledge, London

Beaune D, Fruth B, Bollache L et al (2013) Doom of the elephant-dependent trees in a Congo tropical forest. For Ecol Manag 295:109-117

Berndt L, Brockerhoff EG, Jactel H (2008) Relevance of exotic pine plantations as a surrogate habitat for ground beetles (Carabidae) where native forest is rare. Biodivers Conserv 9:247-261

Binkley D (2003) Seven decades of stand development in mixed and pure stands of conifers and nitrogenfixing red alder. Can J For Res 33:2274-2279

Binkley D, Sollins P, Bell R, Sachs D, Myrold D (1992) Biogeochemistry of adjacent conifer and alderconifer stands. Ecology 73:2022-2033

Binkley D, Stape JL, Bauerle WL, Ryan MG (2010) Explaining growth of individual trees: light interception and efficiency of light use by Eucalyptus at four sites in Brazil. For Ecol Manag 259:1704-1713

Boafo YA, Saito O, Kato S, Kamiyama C, Takeuchi K, Nakahara M (2016) The role of traditional ecological knowledge in ecosystem services management: the case of four rural communities in Northern Ghana. Int J Biodivers Sci Ecosyst Serv Manag 12:24-38. doi:10.1080/21513732.2015.1124454

Bond WJ, Keeley JE (2005) Fire as a global 'herbivore': the ecology and evolution of flammable ecosystems. Trends Ecol Evol 20:387-394

Bond WJ, Midgley JJ (1995) Kill thy neighbour: an individualistic argument for the evolution of flammability. Oikos 73:79-85

Bonnesoeur V (2016) Acclimatation des arbres forestiers au vent: de la perception du vent à ses conséquences sur la croissance et le dimensionnement des tiges. AgroParisTech

Bourdier T, Cordonnier T, Kunstler G, Piedallu C, Lagarrigues G, Courbaud B (2016) Tree size inequality reduces forest productivity: an analysis combining inventory data for ten European species and a light competition model. PLoS ONE 11:e0151852

Boyd IL, Freer-Smith PH, Gilligan CA, Godfray HC (2013) The consequence of tree pests and diseases for ecosystem services. Science 342:1235773. doi:10.1126/science.1235773

Brockerhoff EG, Liebhold AM (2017) Ecology of forest insect invasions. Biol Invas. doi:10.1007/s10530017-1514-1

Brockerhoff EG, Jactel H, Parrotta JA, Quine CP, Sayer J (2008) Plantation forests and biodiversity: oxymoron or opportunity? Biodivers Conserv 17:925-951

Brockerhoff EG, Jactel H, Parrotta JA, Ferraz SF (2013) Role of eucalypt and other planted forests in biodiversity conservation and the provision of biodiversity-related ecosystem services. For Ecol Manag 301:43-50

Brockway DG, Gatewood RG, Paris RB (2002) Restoring fire as an ecological process in shortgrass prairie ecosystems: initial effects of prescribed burning during the dormant and growing seasons. J Environ Manag 65:135-152

Brodie JF, Aslan CE (2012) Halting regime shifts in floristically intact tropical forests deprived of their frugivores. Restor Ecol 20:153-157

Bueno RS, Guevara R, Ribeiro MC et al (2013) Functional redundancy and complementarities of seed dispersal by the last Neotropical megafrugivores. PLoS ONE 8:e56252

Burgar JM, Craig MD, Stokes VL (2015) The importance of mature forest as bat roosting habitat within a production landscape. For Ecol Manag 356:112-123

Campos-Arceiz A, Blake S (2011) Megagardeners of the forest-the role of elephants in seed dispersal. Acta Oecol 37:542-553 
Castagneyrol B, Jactel H (2012) Unraveling plant-animal diversity relationships: a meta-regression analysis. Ecology 93:2115-2124

Castagneyrol B, Jactel H, Vacher C, Brockerhoff EG, Koricheva J (2014a) Effects of plant phylogenetic diversity on herbivory depend on herbivore specialization. J Appl Ecol 51:134-141

Castagneyrol B, Régolini M, Jactel H (2014b) Tree species composition rather than diversity triggers associational resistance to the pine processionary moth. Basic Appl Ecol 15:516-523

Cavanaugh KC, Gosnell JS, Davis SL, Ahumada J, Boundja P, Clark DB, Mugerwa B, Jansen PA, O’Brien TG, Rovero F, Sheil D (2014) Carbon storage in tropical forests correlates with taxonomic diversity and functional dominance on a global scale. Glob Ecol Biogeogr 23:563-573

Chan KMA, Satterfield T, Goldstein J (2012) Rethinking ecosystem services to better address and navigate cultural values. Ecol Econ 74:8-18

Charbonnier Y, Gaüzère P, van Halder I, Nezan J, Barnagaud JY, Jactel H, Barbaro L (2016) Deciduous trees increase bat diversity at stand and landscape scales in mosaic pine plantations. Landsc Ecol 31:291-300

Chavez V, MacDonald E (2012) Partitioning vascular understory diversity in mixedwood boreal forests: the importance of mixed canopies for diversity conservation. For Ecol Manag 271:19-26

Chhatre A, Agrawal A (2009) Trade-offs and synergies between carbon storage and likelihood benefits from forest commons. Proc Natl Acad Sci USA 106(42):17667-17670. doi:10.1073/pnas.0905308106

CICES (2013) Common International Classification of Ecosystem Services (CICES): consultation on version 4, August-December 2012. Centre for Environmental Management, Nottingham. http://cices.eu/ content/uploads/sites/8/2015/09/CICES-V4-3-_-17-01-13a.xlsx

Cockle KL, Martin K, Wesołowski T (2011) Woodpeckers, decay, and the future of cavity-nesting vertebrate communities worldwide. Front Ecol Environ 9:377-382

Conti G, Diaz S (2013) Plant functional diversity and carbon storage-an empirical test in semi-arid forest ecosystems. J Ecol 101:18-28

Cooper-Ellis S, Foster DR, Carlton G, Lezberg A (1999) Forest response to catastrophic wind: results from an experimental hurricane. Ecology 80:2683-2696

Coote L, Dietzsch AC, Wilson MW, Graham CT, Fuller L, Walsh AT, Irwin S, Kelly DL, Mitchell FJG, Kelly TC, O'Halloran J (2013) Testing indicators of biodiversity for plantation forests. Ecol Indic 32:107-115

Corona P, Franceschi S, Pisani C, Portoghesi L, Mattioli W, Fattorini L (2017) Inference on diversity from forest inventories: a review. Biodivers Conserv. doi:10.1007/s10531-015-1017-2

Cortes-Flores J, Andresen E, Cornejo-Tenorio G et al (2013) Fruiting phenology of seed dispersal syndromes in a Mexican neotropical temperate forest. For Ecol Manag 289:445-454

Costanza R, d'Arge R, De Groot R, Farber S, Grasso M, Hannon B, Limburg K, Naeem S, O'neill RV, Paruelo J, Raskin RG (1997) The value of the world's ecosystem services and natural capital. Nature 387:253-260

Côté S, Rooney T, Tremblay J (2004) Ecological impacts of deer overabundance. Annu Rev Ecol Evol Syst 35:113-147

Damien M, Jactel H, Meredieu C, Régolini M, van Halder I, Castagneyrol B (2016) Pest damage in mixed forests: disentangling the effects of neighbour identity, host density and host apparency at different spatial scales. For Ecol Manag 378:103-110

Daniel TC, Muhar A, Arnberger A, Aznar O, Boyd JW, Chan KMA, Costanza R, Elmqvist T, Flint CG, Gobster PH, Gret-Regamey A, Lave R, Muhar S, Penker M, Ribe RG, Schauppenlehner T, Sikor T, Soloviy I, Spierenburg M, Taczanowska K, Tam J, von der Dunk A (2012) Contributions of cultural services to the ecosystem services agenda. Proc NatL Acad Sci USA 109:8812-8819

de Vries FT, Thébault E, Liiri M, Bardgett RD et al (2013) Soil food web properties explain ecosystem services across European land use systems. Proc NatL Acad Sci 110:14296-14301

Decocq G, Andrieu E, Brunet J et al (2016) Ecosystem services from small forest patches in agricultural landscapes. Curr For Rep 2:30-44

Deconchat M, Brockerhoff EG, Barbaro L (2009) Effects of surrounding landscape composition on the conservation value of native and exotic habitats for native forest birds. For Ecol Manag 258:S196$\mathrm{S} 204$

Dickinson MB, Johnson EA (2004) Temperature-dependent rate models of vascular cambium cell mortality. Can J For Res 34:546-559

Dupont S, Pivato D, Brunet Y (2015) Agricultural and forest meteorology wind damage propagation in forests. Agric For Meteorol 214-215:243-251. doi:10.1016/j.agrformet.2015.07.010

Edwards D, Collins T, Goto R (2016) Does the conservation status of a Caledonian forest also indicate cultural ecosystem value. In: Agnoletti M, Emanueli F (eds) Biocultural diversity in Europe. Springer, New York 
Everham EM III, Brokaw NVL (1996) Forest damage and recovery from catastrophic wind. Bot Rev 62:113-185

Fagerholm N, Käyhkö N, Ndumbaro F, Khamis M (2012) Community stakeholders' knowledge in landscape assessments-mapping indicators for landscape services. Ecol Indic 18:421-433

Fahrig L (2003) Effects of habitat fragmentation on biodiversity. Annu Rev Ecol Evol Syst 34:487-515

Fahrig L et al (2015) Farmlands with smaller crop fields have higher within-field biodiversity. Agric Ecosyst Environ 200:219-234

FAO (2015) global forest resources assessment 2015. FAO (Food and Agriculture Organization of the United Nations), Rome

Farwig N, Sajita N, Bohning-Gaese K (2008) Conservation value of forest plantations for bird communities in western Kenya. For Ecol Manag 255:3885-3892

Fernandes P, Luz A, Loureiro C (2010) Changes in wildfire severity from maritime pine woodland to contiguous forest types in the mountain of northwestern Portugal. For Ecol Manag 260:883-892

Fernandez-Conradi P, Jactel H, Hampe A, Leiva MJ, Castagneyrol B (2017) The effect of tree genetic diversity on insect herbivory varies with insect abundance. Ecosphere 8:e01637. doi:10.1002/ecs2. 1637

Finegan B, Peña-Claros M, Oliveira A, Ascarrunz N, Bret-Harte MS, Carreño-Rocabado G, Casanoves F, Díaz S, Eguiguren Velepucha P, Fernandez F, Licona JC (2015) Does functional trait diversity predict above-ground biomass and productivity of tropical forests? Testing three alternative hypotheses. J Ecol 103:191-201

Forest Peoples Programme (2017) Forest peoples programme. Fosseway Business Centre, Moreton-inMarsh. www.forestpeoples.org

Forrester DI (2014) The spatial and temporal dynamics of species interactions in mixed-species forests: from pattern to process. For Ecol Manag 312:282-292

Forrester DI, Bauhus J (2016) A review of processes behind diversity-productivity relationships in forests. Curr For Rep 2:45-61

Forrester DI, Kohnle U, Albrecht AT, Bauhus J (2013) Complementarity in mixed-species stands of Abies alba and Picea abies varies with climate, site quality and stand density. For Ecol Manag 304:233-242

Forrester DI, Ammer C, Annighöfer PJ, Bravo-Oviedo A et al (2017) Using the 3-PGmix model to predict the spatial and temporal dynamics of species interactions in Fagus sylvatica and Pinus sylvestris forests across Europe. For Ecol Manag 405:112-133

Freer-Smith PH, Webber JF (2017) Tree pests and diseases: the threat to biodiversity and the delivery of ecosystem services. Biodiv Conserv. doi:10.1007/s10531-015-1019-0

Fründ J, Dormann CF, Holzschuh A, Tscharntke T (2013) Bee diversity effects on pollination depend on functional complementarity and niche shifts. Ecology 94:2042-2054

Gamfeldt L, Snall T, Bagchi R, Bengtsson J et al (2013) Higher levels of multiple ecosystem services are found in forests with more tree species. Nat Commun $4: 1340$. doi:10.1038/ncomms 2328

Garcia D, Martinez D (2012) Species richness matters for the quality of ecosystem services: a test using seed dispersal by frugivorous birds. Proc R Soc B 279:3106-3113

Gardiner B, Marshall B, Achim A, Belcher R, Wood C (2005) The stability of different silvicultural systems: a wind-tunnel investigation. Forestry 78:471-484

Gardiner B, Schuck A, Schelhaas M-J, Orazio C, Blennow K, Nicoll B (2013) Living with storm damage to forests: what science can tell us. Eur For Inst, Joensuu

Garibaldi LA, Steffan-Dewenter I, Winfree R, Aizen MA, Bommarco R, Cunningham SA, Kremen C, Carvalheiro LG, Harder LD, Afik O, Bartomeus I (2013) Wild pollinators enhance fruit set of crops regardless of honey bee abundance. Science 339:1608-1611

Gibson L, Lee TM, Koh LP, Sodhi NS et al (2011) Primary forests are irreplaceable for sustaining tropical biodiversity. Nature 478:378-381

Gonzales RS, Ingle NR, Lagunzad DA, Nakashizuka T (2009) Seed dispersal by birds and bats in lowland Philippine forest successional area. Biotropica 41:452-458

Gonzalez P, Kroll B, Vargas CR (2014) Tropical rainforest biodiversity and aboveground carbon changes and uncertainties in the Selva Central, Peru. For Ecol Manag 312:78-91

González JR, Palahi M, Trasobares A, Pukkala T (2006) A fire probability model for forest stands in Catalonia (north-east Spain). Ann For Sci 63:169-176

González JR, Trasobares A, Palahi M, Pukkala T (2007) Predicting stand damage and tree survival in burned forests in Catalonia (North-East Spain). Ann For Sci 64:733-742

Gonzalez-Varo JP, Lopez-Bao JV, Guitian J (2013) Functional diversity among seed dispersal kernels generated by carnivorous mammals. J Anim Ecol 82:562-571

Gould RK, Ardoin NM, Woodside U, Satterfield T, Hannahs N, Daily GC (2014) The forest has a story: cultural ecosystem services in Kona, Hawai 'i. Ecol Soc 19:55. doi:10.5751/ES-06893-190355 
Graham CT, Wilson MW, Gittings T, Kelly TC, Irwin S, Quinn JL, O'Halloran J (2017) Implications of afforestation for bird communities: the importance of preceding land-use type. Biodiv Conserv. doi:10. 1007/s10531-015-0987-4

Gregory RD, Vorisek P, van Strien A, Gmelig Meyling AW, Jiguet F, Fornasari L, Reif J, Chylarecki P, Burfield IJ (2007) Population trends of widespread woodland birds in Europe. Ibis 149:78-97

Guyot V, Castagneyrol B, Vialatte A, Deconchat M, Selvi F, Bussotti F, Jactel H (2015) Tree diversity limits the impact of an invasive forest pest. PLoS ONE 10:e0136469

Guyot V, Castagneyrol B, Vialatte A, Deconchat M, Jactel H (2016) Tree diversity reduces pest damage in mature forests across Europe. Biol Lett 12:20151037

Hambäck PA, Englund G (2005) Patch area, population density and the scaling of migration rates: the resource concentration hypothesis revisited. Ecol Lett 8:1057-1065

Hanewinkel M, Albrecht A, Schmidt M (2013) Influence of stand characteristics and landscape structure on wind damage. In: Gardiner B, Schuck A, Schelhaas M, Orazio C, Blennow K, Nicoll B (eds) Living with storm damage to forests: what science can tell us. Eur For Inst, Joensuu, pp 41-47

Harmon ME, Fasth B, Woodall CW, Sexton J (2013) Carbon concentration of standing and downed woody detritus: effects of tree taxa, decay class, position, and tissue type. For Ecol Manag 291:259-267

Häyhä T, Franzese PP, Alessandro Paletto A, Fath BD (2015) Assessing, valuing, and mapping ecosystem services in alpine forests. Ecosyst Serv 14:12-23

Hector A, Bagchi R (2007) Biodiversity and ecosystem multifunctionality. Nature 448:188-190. doi:10. 1038/nature05947

Hooper DU, Chapin FS, Ewel JJ, Hector A, Inchausti P, Lavorel S, Lawton JH, Lodge DM, Loreau M, Naeem S, Schmid B (2005) Effects of biodiversity on ecosystem functioning: a consensus of current knowledge. Ecol Monogr 75:3-35

Irwin S, Pedley S, Coote L, Dietzsch A, Wilson M, Oxbrough A, Sweeney O, Moore K, Martin R, Kelly D, Mitchell FG, Kelly T, O'Halloran J (2014) The value of plantation forests for plant, invertebrate and bird diversity and the potential for cross-taxon surrogacy. Biodivers Conserv 23:697-714

Isbell F, Calcagno V, Hector A et al (2011) High plant diversity is needed to maintain ecosystem services. Nature 477:199-202

Isbell F, Craven D, Connolly J, Loreau M, Eisenhauer N et al (2015) Biodiversity increases the resistance of ecosystem productivity to climate extremes. Nature 526:574-577

Jactel H, Brockerhoff EG (2007) Tree diversity reduces herbivory by forest insects. Ecol Lett 10:835-848

Jactel H, Brockerhoff E, Duelli P (2005) A test of the biodiversity-stability theory: Meta-analysis of tree species diversity effects on insect pest infestations, and re-examination of responsible factors. In: Scherer-Lorenzen M, Körner C, Schulze ED (eds) Forest diversity and function: temperate and boreal systems. Springer, New York, pp 235-262

Jactel H, Menassieu P, Vetillard F, Gaulier A, Samalens JC, Brockerhoff EG (2006) Tree species diversity reduces the invasibility of maritime pine stands by the bast scale, Matsucoccus feytaudi (Homoptera: margarodidae). Can J For Res 36:314-323

Jactel H, Birgersson G, Andersson S, Schlyter F (2011) Non-host volatiles mediate associational resistance to the pine processionary moth. Oecologia 166:703-711

Jactel H, Bauhus J, Boberg J, Bonal D, Castagneyrol B, Gardiner B, Gonzalez-Olabarria JR, Koricheva J, Meurisse N, Brockerhoff EG (2017) Tree diversity drives forest stand resistance to natural disturbances. Curr For Rep 3:223-243

Jesus FM, Pivello VR, Meirelles ST et al (2012) The importance of landscape structure forest seed dispersal in rain forest fragments. J Veg Sci 23:1126-1136

Jönsson MT, Ruete A, Kellner O, Gunnarsson U, Snäll T (2017) Will forest conservation areas protect functionally important diversity of fungi and lichens over time? Biodivers Conserv 26:2547-2567

Jung K, Kaiser S, Böhm S, Nieschulze J, Kalko EKV (2012) Moving in three dimensions: effects of structural complexity on occurrence and activity of insectivorous bats in managed forest stands. J Appl Ecol 49:523-531

Keenan RJ, Reams GA, Achard F et al (2015) Dynamics of global forest area: results from the FAO global forest resources assessment 2015. For Ecol Manag 352:9-20

Kelty MJ (1992) Comparative productivity of monocultures and mixed-species stands. In: Kelty MJ, Larson BC, Oliver CD (eds) The ecology and silviculture of mixed-species forests. Kluwer Academic Publishers, Dordrecht, pp 125-141

Kennedy CM et al (2013) A global quantitative synthesis of local and landscape effects on wild bee pollinators in agroecosystems. Ecol Lett 16:584-599

Kirby KR, Potvin C (2007) Variation in carbon storage among tree species: implications for the management of a small-scale carbon sink project. For Ecol Manag 246:208-221 
Klein AM, Vaissiere BE, Cane JH, Steffan-Dewenter I, Cunningham SA, Kremen C, Tscharntke T (2007) Importance of pollinators in changing landscapes for world crops. Proc R Soc Lond B 274:303-313

Kozlov MV, Lanta V, Zverev V, Zvereva EL (2015) Background losses of woody plant foliage to insects show variable relationships with plant functional traits across the globe. J Ecol 103:1519-1528

Kurz WA, Dymond CC, Stinson G, Rampley GJ, Neilson ET, Carroll AL, Ebata T, Safranyik L (2008) Mountain pine beetle and forest carbon feedback to climate change. Nature 452:987-990

Lange M, Eisenhauer N, Sierra CA, Bessler H, Engels C, Griffiths RI, Mellado-Vázquez PG, Malik AA, Roy J, Scheu S, Steinbeiss S, Thomson BC, Trumbore SE, Gleixner G (2015) Plant diversity increases soil microbial activity and soil carbon storage. Nat Commun 6:6707. doi:10.1038/ncomms7707

Lebourgeois F, Gomez N, Pinto P, Mérian P (2013) Mixed stands reduce Abies alba tree-ring sensitivity to summer drought in the Vosges mountains, western Europe. For Ecol Manag 303:61-71

Lefcheck JS, Byrnes JE, Isbell F, Gamfeldt L, Griffin JN, Eisenhauer N, Hensel MJ, Hector A, Cardinale BJ, Duffy JE (2015) Biodiversity enhances ecosystem multifunctionality across trophic levels and habitats. Nat Commun 6:6936. doi:10.1038/ncomms7936

Lehouck V, Spanhove T, Colson L et al (2009) Habitat disturbance reduces seed dispersal of a forest interior tree in a fragmented African cloud forest. Oikos 118:1023-1034

Liang J, Crowther TW, Picard N, Wiser S, Reich PB, et al (2016) Positive biodiversity-productivity relationship predominant in global forests. Science 354:aaf8957. doi:10.1126/science.aaf8957

Liebhold AM, McCullough DG, Blackburn LM, Frankel SJ, Von Holle B, Aukema JE (2013) A highly aggregated geographical distribution of forest pest invasions in the USA. Divers Distrib 19:1208-1216

Lindenmayer DB (2009) Forest wildlife management and conservation. Ann NY Acad Sci 1162:284-310

Lindenmayer DB (2017) Conserving large old trees as small natural features. Biol Conserv 211:51-59

Lindenmayer DB, Franklin JF (2002) Conserving forest biodiversity: a comprehensive multiscaled approach. Island Press, Washington

Lindenmayer D, Blanchard W, Tennant P, Barton P, Ikin K, Mortelliti A, Okada S, Crane M, Michael D (2015) Richness is not all: how changes in avian functional diversity reflect major landscape modification caused by pine plantations. Divers Distrib 21:836-847

Linnell MA, Davis RJ, Lesmeister DB, Swingle JK (2017) Conservation and relative habitat suitability for an arboreal mammal associated with old forest. For Ecol Manag 402:1-11

Lovelock CE, Ewel JJ (2005) Links between tree species, symbiotic fungal diversity and ecosystem functioning in simplified tropical ecosystems. New Phytol 167:219-228

Lutz DA, Burakowski EA, Murphy MB, Borsuk ME, Niemiec RM, Howarth RB (2016) Trade-offs between three forest ecosystem services across the state of New Hampshire, USA: timber, carbon, and albedo. Ecol Appl 26:146-161. doi:10.1890/14-2207

Luu TC, Binkley D, Stape JL (2013) Neighborhood uniformity increases growth of individual Eucalyptus trees. For Ecol Manag 289:90-97

Lyver PO’B, Timoti P, Gormley A, Jones CJ, Richardson SJ, Tahi BL, Greenhalgh S (2017a) Key Māori values strengthen the mapping of forest ecosystem services. Ecosyst Serv 27:92-102

Lyver PO'B, Timoti P, Jones CJ, Richardson SJ, Tahi BL, Greenhalgh S (2017b) An indigenous community-based monitoring system for assessing forest health in New Zealand. Biodiv Conserv. doi:10. 1007/s10531-016-1142-6

Mace G, Masundire H, Baillie J et al (2005) Biodiversity. In: Hassan R, Scholes R, Ash N (eds) Ecosystems and human well-being: current state and trends: findings of the condition and trends working group (chapter 4); Millennium ecosystem assessment. Island Press, Washington

Mace GM, Norris K, Fitter AH (2012) Biodiversity and ecosystem services: a multilayered relationship. Trends Ecol Evol 27:19-26. doi:10.1016/j.tree.2011.08.006

Markl JS, Schleuning M, Forestget PM et al (2012) Meta-analysis of the effects of human disturbance on seed dispersal by animals. Conserv Biol 26:1072-1081

Martín-Alcón S, Coll L, De Cáceres M, Guitart L, Cabré M, Just A, González-Olabarría JR (2015) Combining aerial LiDAR and multispectral imagery to assess postfire regeneration types in a Mediterranean forest. Can J For Res 45:856-866

Michener CD (2007) The bees of the world, 2nd edn. The Johns Hopkins University Press, Baltimore

Milcu AI, Hanspach J, Abson D, Fischer J (2013) Cultural ecosystem services: a literature review and prospects for future research. Ecol Soc 18:44. doi:10.5751/ES-05790-180344

Millennium Ecosystem Assessment (MEA) (2005) Ecosystems and human well-being. Island Press, Washington

Mitchell MGE, Bennett EM, Gonzalez A (2014) Forest fragments modulate the provision of multiple ecosystem services. J Appl Ecol 51:909-918. doi:10.1111/1365-2664.12241

Monge JJ, Parker WJ, Richardson JW (2016) Integrating forest ecosystem services into the farming landscape: a stochastic economic assessment. J Environ Manage 174:87-99 
Moreira X, Abdala-Roberts L, Parra-Tabla V, Mooney KA (2014) Positive effects of plant genotypic and species diversity on anti-herbivore defenses in a tropical tree species. PLoS ONE 9:e105438

Mori AS, Isbell F, Fujii S, Makoto K, Matsuoka S, Osono T (2016) Low multifunctional redundancy of soil fungal diversity at multiple scales. Ecol Lett 19:249-259. doi:10.1007/s11284-016-1367-6

Mori AS, Lertzman KP, Gustafsson L (2017) Biodiversity and ecosystem services in forest ecosystems: a research agenda for applied forest ecology. J Appl Ecol 54:12-27

Muiruri EW, Rainio K, Koricheva J (2016) Do birds see the forest for the trees? Scale-dependent effects of tree diversity on avian predation of artificial larvae. Oecologia 180:619-630

Neumann JL, Holloway GJ, Hoodless A, Griffiths GH (2017) The legacy of 20th Century landscape change on today's woodland carabid communities. Divers Distrib. doi:10.1111/ddi.12652

Newbold T, Hudson LN, Hill SLL et al (2015) Global effects of land use on local terrestrial biodiversity. Nature 520:45-50

Nikula A, Heikkinen S, Helle E (2004) Habitat selection of adult moose Alces alces at two spatial scales in central Finland. Wildl Biol 10:121-135

O'Callaghan CJ, Irwin S, Byrne KA, O'Halloran J (2017) The role of planted forests in the provision of habitat: an Irish perspective. Biodivers Conserv. doi:10.1007/s10531-016-1125-7

Ollerton J, Winfree R, Tarrant S (2011) How many flowering plants are pollinated by animals? Oikos 120:321-326

Osuri AM, Kumar VS, Sankaran M (2014) Altered stand structure and tree allometry reduce carbon storage in evergreen forest fragments in India's Western Ghats. For Ecol Manag 329:375-383

Oxbrough A, Gittings T, O'Halloran J, Giller P, Kelly TC (2007) Biodiversity of the ground-dwelling spider fauna of afforestation habitats. Agric Ecosyst Environ 120:433-441

Oxbrough A, García-Tejero S, Spence J, O’Halloran J (2016) Can mixed stands of native and non-native tree species enhance diversity of epigaeic arthropods in plantation forests? For Ecol Manag 367:21-29

Pachauri RK, Allen MR, Barros VR, et al (2014) Climate change 2014: synthesis report. Contribution of Working Groups I, II and III to the fifth assessment report of the Intergovernmental Panel on Climate Change. IPCC, Geneva

Paquette A, Messier C (2010) The role of plantations in managing the world's forests in the Anthropocene. Front Ecol Environ 8:27-34

Payn T, Carnus JM, Freer-Smith P, Kimberley M, Kollert W, Liu S, Orazio C, Rodriguez L, Silva LN, Wingfield MJ (2015) Changes in planted forests and future global implications. For Ecol Manag 352:57-67. doi:10.1016/j.foreco.2015.06.021

Penaluna BE, Olson DH, Flitcroft RL, Weber MA, Bellmore JR, Wondzell SM, Dunham JB, Johnson SL, Reeves GH (2017) Aquatic biodiversity in forests: a weak link in ecosystem services resilience. Biodiv Conserv. doi:10.1007/s10531-016-1148-0

Pert PL, Hill R, Maclean K, Dale A, Rist P, Schmider J, Talbot L, Tawake L (2015) Mapping cultural ecosystem services with rainforest aboriginal peoples: integrating biocultural diversity, governance and social variation. Ecosyst Serv 13:41-56

Phifer CC, Knowlton JL, Webster CR, Flaspohler DJ, Licata JA (2017) Bird community responses to afforested eucalyptus plantations in the Argentine pampas. Biodivers Conserv. doi:10.1007/s10531016-1126-6

Plath M, Dorn S, Barrios H, Mody K (2012) Diversity and composition of arboreal beetle assemblages in tropical pasture afforestations: effects of planting schemes and tree species identity. Biodivers Conserv 21:3423-3444

Plieninger T, Sebastian Dijks S, Oteros-Rozas E, Bieling C (2013) Assessing, mapping and quantifying cultural ecosystem services at community level. Land Use Pol 33:118-129

Potts SG, Biesmeijer JC, Kremen C, Neumann P, Schweiger O, Kunin WE (2010) Global pollinator declines: trends, impacts and drivers. Trends Ecol Evol 25:345-353

Potts SG, Imperatriz-Fonseca VL, Ngo HT, Biesmeijer JC, Breeze TD, Dicks LV, Garibaldi LA, Hill R, Settele J, Vanbergen AJ (2016) Summary for policymakers of the assessment report of the Intergovernmental Science-Policy Platform on Biodiversity and Ecosystem Services on pollinators, pollination and food production. https://www.actu-environnement.com/media/pdf/news-26331-syntheseipbes-decideurs-pollinisateurs.pdf

Pretzsch H, Forrester DI (2017) Stand dynamics of mixed-species stands compared with monocultures. In: Pretzsch H, Forrester DI, Bauhus J (eds) Mixed-species forests-ecology and management. Springer, Berlin, pp 117-209

Pretzsch H, Forrester DI, Bauhus J (eds) (2017) Mixed-species forests-ecology and management. Springer, Berlin

Proctor M, Yeo P, Lack A (1996) The natural history of pollination. HarperCollins, New York 
Puydarieux P, Beyou W (2017) Evaluation française des écosystèmes et des services écosystémique—cadre conceptuel. Ministère de l'Environnement \& Fondation pour la Recherche sur la Biodiversité. https:// www.ecologique-solidaire.gouv.fr/sites/default/files/Thema\%20-\%20Efese\%20-\%20Le\%20cadre\% 20conceptuel.pdf

Quine CP, Malcolm DC (2007) Wind-driven gap development in Birkley Wood, a long-term retention of planted Sitka spruce in upland Britain. Can J For Res 37:1787-1796. doi:10.1139/X07-051

Ratcliffe S, Wirth C, Jucker T, Baeten L et al (2017) in press) Biodiversity and ecosystem functioning relations in European forests depend on environmental context. Ecol Lett. doi:10.1111/ele.12849

Ribe RG (2005) Aethetic perceptions of green tree retention harvests in vista views. The interaction of cut level, retention pattern and harvest shape. Landsc Urban Plan 73:277-293

Richards AE, Forrester DI, Bauhus J, Scherer-Lorenzen M (2010) The influence of mixed tree plantations on the nutrition of individual species: a review. Tree Physiol 30:1192-1208

Rickenbach O, Reyes-Gracía V, Moser G, García C (2017) What explains wildlife value orientations? A study among Central African forest dwellers. Hum Ecol 45:293-306

Root RB (1973) Organization of a plant-arthropod association in simple and diverse habitats: the fauna of collards (Brassica oleracea). Ecol Monogr 43:95-124

Rubene D, Schroeder M, Ranius T (2015) Diversity patterns of wild bees and wasps in managed boreal forests: effects of spatial structure, local habitat and surrounding landscape. Biol Conserv 184:201-208

Ruffell J, Clout MN, Didham RK (2017) The matrix matters, but how should we manage it? Estimating the amount of high-quality matrix required to maintain biodiversity in fragmented landscapes. Ecography 40:171-178

Ryan MG, Stape JL, Binkley D, Silva GGC et al (2010) Factors controlling Eucalyptus productivity: how water availability and stand structure alter production and carbon allocation. For Ecol Manag 259:1695-1703

Sangha KK, Russell-Smith J (2017) Towards an indigenous ecosystems services valuation framework: a north Australian example. Conserv Soc 15:255-269

Santaniello F, Djupström LB, Ranius T, Weslien J, Rudolphi J, Thor G (2017) Large proportion of wood dependent lichens in boreal pine forest are confined to old hard wood. Biodivers Conserv 26:1295-1310

Schröter D, Cramer W, Leemans R, Zierl B et al (2005) Ecosystem service supply and vulnerability to global change in Europe. Science 310:1333-1337

Schuldt A, Baruffol M, Böhnke M et al (2010) Tree diversity promotes insect herbivory in subtropical forests of south-east China. J Ecol 98:917-926

Schulze ED, Mooney HA (eds) (2012) Biodiversity and ecosystem function. Springer, Heidelberg

Seibold S, Bassler C, Brandl R, Gossner MM, Thom S, Ulyshen MD, Muller J (2015) Experimental studies of dead-wood biodiversity - a review identifying global gaps in knowledge. Biol Conserv 191:139-149

Seidler TG, Plotkin JB (2006) Seed dispersal and spatial pattern in tropical trees. PLoS Biol 4:e344. doi:10. 1371/journal.pbio.0040344

Shirima DD, Totland Ø, Munishi PK, Moe SR (2015) Relationships between tree species richness, evenness and aboveground carbon storage in montane forests and miombo woodlands of Tanzania. Basic Appl Ecol 16:239-249

Sholes OD (2008) Effects of associational resistance and host density on woodland insect herbivores. J Anim Ecol 77:16-23

Smith GF, Gittings T, Wilson M, French L, Oxbrough A, O'Donoghue S, O'Halloran J, Kelly DL, Mitchell FJG, Kelly T, Iremonger S, McKee A-M, Giller P (2008) Identifying practical indicators of biodiversity for stand-level management of plantation forests. Biodivers Conserv 17:991-1015

Soares AAV, Leite HG, Souza AL, Silva SR, Lourenço HM, Forrester DI (2016) Increasing stand structural heterogeneity reduces productivity in Brazilian Eucalyptus monoclonal stands. For Ecol Manag 373:26-32

Staab M, Schuldt A, Assmann T, Klein A (2014) Tree diversity promotes predator but not omnivore ants in a subtropical Chinese forest. Ecol Entomol 39:637-647

Stanturf JA, Goodrick SL, Outcalt KW (2007) Disturbance and coastal forests: a strategic approach to forest management in hurricane impact zones. For Ecol Manag 250:119-135. doi:10.1016/j.foreco.2007.03. 015

Stape JL, Binkley D, Ryan MG, Azevedo MR et al (2010) The Brazil Eucalyptus potential productivity project: influence of water, nutrients and stand uniformity on wood production. For Ecol Manag 259:1684-1694

Sturtevant BR, Miranda BR, Yang J, He HS, Gustafson EJ, Scheller RM (2009) Studying fire mitigation strategies in multi-ownership landscapes: balancing the management of fire-dependent ecosystems and fire risk. Ecosystems 12:445-461 
Styring AR, Ragai R, Unggang J, Stuebing R, Hosner PA, Sheldon FH (2011) Bird community assembly in Bornean industrial tree plantations: effects of forest age and structure. For Ecol Manag 261:531-544

Taki H, Inoue T, Tanaka H, Makihara H, Sueyoshi M, Isono M, Okabe K (2010) Responses of community structure, diversity, and abundance of understory plants and insect assemblages to thinning in plantations. For Ecol Manag 259:607-613

Taki H, Yamaura Y, Okabe K, Maeto K (2011) Plantation vs. natural forest: matrix quality determines pollinator abundance in crop fields. Sci Rep 1:132. doi:10.1038/srep00132

Taki H, Okochi I, Okabe K, Inoue T, Goto H, Matsumura T, Si Makino (2013) Succession influences wild bees in a temperate forest landscape: the value of early successional stages in naturally regenerated and planted forests. PLoS ONE 8:e56678

Taki H, Ikeda H, Nagamitsu T, Yasuda M, Sugiura S, Maeto K, Okabe K (2017) Stable nitrogen and carbon isotope ratios in wild native honeybees: the influence of land use and climate. Biodiv Conserv. doi:10. 1007/s10531-016-1114-X

Terborgh J, Nunez-Iturii G, Pitman NCA, Cornejo-Valverde FH, Alvarez P, Swamy V, Pringle EG, Paine CET (2008) Tree recruitment in an empty forest. Ecology 89:1757-1768

Thom D, Seidl R (2016) Natural disturbance impacts on ecosystem services and biodiversity in temperate and boreal forests. Biol Rev 91:760-781. doi:10.1111/brv.12193

Thompson ID, Okabe K, Tylianakis JM et al (2011) Forest biodiversity and the delivery of ecosystem goods and services: translating science into policy. Bio Sci 61:972-981

Thompson ID, Okabe K, Parrotta JA, Brockerhoff E, Jactel H, Forrester DI, Taki H (2014) Biodiversity and ecosystem services: lessons from nature to improve management of planted forests for REDD-plus. Biodiv Conserv 23:2613-2635

Traveset A (1998) Effect of seed passage through vertebrate frugivores' guts on germination: a review. Perspect Plant Ecol Evol Syst 1:151-190

Turner RK, Van Den Bergh JC, Söderqvist T, Barengregt A, Van Der Straaten J, Maltby E, Van Ierland EC (2000) Ecological-economic analysis of wetlands: scientific integration for management and policy. Ecol Econ 35:7-23

Tylianakis JM, Rand TA, Kahmen A, Klein A-M, Buchmann N, Perner J, Tscharntke T (2008) Resource heterogeneity moderates the biodiversity-function relationship in real world ecosystems. PLoS Biol 6:e122

Ulanova NG (2000) The effects of windthrow on forests at different spatial scales: a review. For Ecol Manag 135:155-167

Ulyshen MD (2016) Wood decomposition as influenced by invertebrates. Biol Rev 91:70-85

Unsicker SB, Oswald A, Köhler G, Weisser WW (2008) Complementarity effects through dietary mixing enhance the performance of a generalist insect herbivore. Oecologia 156:313-324

van der Plas F, Manning P, Allan E, Fischer M et al (2016a) Jack-of-all-trades effects drive biodiversityecosystem multifunctionality relationships in European forests. Nat Commun 7:11109. doi:10.1038/ ncomms 11109

van der Plas F, Manning P, Soliveres S, Fischer M et al (2016b) Biotic homogenisation can decrease landscape scale ecosystem multifunctionality. Proc Natl Acad Sci USA 113:357-362. doi:10.1073/ pnas. 1517903113

van der Plas F, Ratcliffe S, Ruiz-Benito P, Allan E et al (2017) Continental mapping of forest ecosystem functions reveals a high but unrealized potential for forest multifunctionality. Ecol Lett. doi:10.1111/ ele. 12868

Vangansbeke P, Blondeel H, Landuyt D, De Frenne P, Gorissen L, Verheyen K (2017) Spatially combining wood production and recreation with biodiversity conservation. Biodiv Conserv. doi:10.1007/s10531016-1135-5

Veres A, Petit S, Conord C, Lavigne C (2013) Does landscape composition affect pest abundance and their control by natural enemies? A review. Agric Ecosyst Environ 166:110-117

Verkerk PJ, Mavsar R, Giergiczny M, Linder M, Edwards D, Schelhaas MJ (2014) Assessing impacts of increased biomass production and biodiversity protection on ecosystem services provided by European forests. Ecosyst Serv 9:155-165. doi:10.1016/j.ecoser.2014.06.004

Verschut TA, Becher PG, Anderson P, Hambäck PA (2016) Disentangling associational effects: both resource density and resource frequency affect search behaviour in complex environments. Funct Ecol 30:1826-1833

Vilà M, Hulme PE (eds) (2016) Impact of biological invasions on ecosystem services. Springer, Cham

Wardle DA (2001) Experimental demonstration that plant diversity reduces invasibility-evidence of a biological mechanism or a consequence of sampling effect? Oikos 95:161-170

Wear DN, Greis JG (2002) The southern forest resource assessment: summary report. General Technical Report SRS-54, USDA Forest Service, Asheville, NC 
Wehncke EV, Dominguez CA (2007) Seed dispersal Ecol of non-restricted frugivores capuchin monkeys in three neotropical forests. J Trop Ecol 23:519-528

White JA, Whitham TG (2000) Associational susceptibility of cottonwood to a box elder herbivore. Ecology 81:1795-1803

Wilson MW, Irwin S, Norriss DW, Newton SF, Collins K, Kelly TC, O'Halloran J (2009) The importance of pre-thicket conifer plantations for nesting Hen Harriers Circus cyaneus in Ireland. Ibis 151:332-343

Winfree R, Griswold T, Kremen C (2007) Effect of human disturbance on bee communities in a forested ecosystem. Conserv Biol 21:213-223

Wolf A, Møller PF, Bradshaw RHW, Bigler J (2004) Storm damage and long-term mortality in a seminatural, temperate deciduous forest. For Ecol Manag 188:197-210

Zandersen M, Termansen M (2012) TEEB Nordic case: Assessing recreational values of Danish forests to guide national plans for afforestation. In: Kettunen M, Vihervaara P, Kinnunen S, D'Amato D, Badura T, Argimon M, Ten Brink P (eds) Socio-economic importance of ecosystem services in the Nordic Countries-Scoping assessment in the context of The Economics of Ecosystems and Biodiversity (TEEB). Nordic Council of Ministers, Copenhagen

Zhao J, Wan S, Fu S, Wang X, Wang M, Liang C, Chen Y, Zhu X (2013) Effects of understory removal and nitrogen fertilization on soil microbial communities in Eucalyptus plantations. For Ecol Manag 310:80-86

Zvereva EL, Zverev V, Kozlov MV (2012) Little strokes fell great oaks: minor but chronic herbivory substantially reduces birch growth. Oikos 121:2036-2043 